\title{
Did Adria rotate relative to Africa?
}

\author{
D. J. J. van Hinsbergen ${ }^{1}$, M. Mensink ${ }^{1}$, C. G. Langereis ${ }^{1}$, M. Maffione ${ }^{1}$, L. Spalluto ${ }^{2}$, M. Tropeano ${ }^{2}$, and L. Sabato ${ }^{2}$ \\ ${ }^{1}$ Department of Earth Sciences, Utrecht University, Budapestlaan 4, 3584 CD Utrecht, the Netherlands \\ ${ }^{2}$ Dipartimento di Scienze della Terra e Geoambientali, Universitaİ degli Studi “Aldo Moro” di Bari, Via E. Orabona 4, \\ 70125, Bari, Italy
}

Correspondence to: D. J. J. van Hinsbergen (d.j.j.vanhinsbergen@uu.nl)

Received: 17 March 2014 - Published in Solid Earth Discuss.: 28 March 2014

Revised: 28 May 2014 - Accepted: 2 June 2014 - Published: 2 July 2014

\begin{abstract}
The first and foremost boundary condition for kinematic reconstructions of the Mediterranean region is the relative motion between Africa and Eurasia, constrained through reconstructions of the Atlantic Ocean. The Adria continental block is in a downgoing plate position relative to the strongly curved central Mediterranean subductionrelated orogens, and forms the foreland of the Apennines, Alps, Dinarides, and Albanides-Hellenides. It is connected to the African plate through the Ionian Basin, likely with Lower Mesozoic oceanic lithosphere. If the relative motion of Adria versus Africa is known, its position relative to Eurasia can be constrained through a plate circuit, thus allowing robust boundary conditions for the reconstruction of the complex kinematic history of the Mediterranean region. Based on kinematic reconstructions for the Neogene motion of Adria versus Africa, as interpreted from the Alps and from Ionian Basin and its surrounding areas, it has been suggested that Adria underwent counterclockwise (ccw) vertical axis rotations ranging from $\sim 0$ to $20^{\circ}$. Here, we provide six new paleomagnetic poles from Adria, derived from the Lower Cretaceous to Upper Miocene carbonatic units of the Apulian peninsula (southern Italy). These, in combination with published poles from the Po Plain (Italy), the Istrian peninsula (Croatia), and the Gargano promontory (Italy), document a post-Eocene $9.8 \pm 9.5^{\circ}$ counterclockwise vertical axis rotation of Adria. Our results do not show evidence of significant Africa-Adria rotation between the Early Cretaceous and Eocene. Models based on reconstructions of the Alps, invoking $17^{\circ} \mathrm{ccw}$ rotation, and based on the Ionian Basin, invoking $2^{\circ} \mathrm{ccw}$ rotation, are both permitted within the documented rotation range, yet are mutually exclusive. This apparent enigma could possibly be solved only if one or more of the following conditions are satisfied: (i) Neogene shorten-
\end{abstract}

ing in the western Alps has been significantly underestimated (by as much as $150 \mathrm{~km}$ ); (ii) Neogene extension in the Ionian Basin has been significantly underestimated (by as much as $420 \mathrm{~km}$ ); and/or (iii) a major sinistral strike-slip zone has decoupled northern and southern Adria in Neogene time. Here we present five alternative reconstructions of Adria at $20 \mathrm{Ma}$, highlighting the kinematic uncertainties, and satisfying the inferred rotation pattern from this study and/or from previously proposed kinematic reconstructions.

\section{Introduction}

The complex geodynamic evolution of the central Mediterranean region has been dominated by convergent motion between the African and European plates. Rather than being accommodated along a discrete plate boundary, the complex paleogeography of the region led to convergence being accommodated along segmented subduction zones, and to distributed overriding plate shortening. In addition, subduction rollback since the late Eocene has formed a series of extensional back-arc basins and strongly curved subduction zones and associated mountain belts (e.g., Dewey et al., 1989; Doglioni et al., 1997; Gueguen et al., 1998; Wortel and Spakman, 2000; Rosenbaum and Lister, 2004; Jolivet et al., 2009; Stampfli and Hochard, 2009). It is this complex evolution that has made the Mediterranean region instrumental in the development of fundamental concepts that link surface deformation to deep mantle processes (Malinverno and Ryan, 1986; Doglioni, 1991; Wortel and Spakman, 2000; Cavazza et al., 2004; Govers and Wortel, 2005; Jolivet et al., 2009; Faccenna and Becker, 2010; Carminati et al., 2012). 
Detailed kinematic reconstructions constitute a fundamental tool for advancing our understanding of the complex geodynamics of the Mediterranean region. A common boundary condition adopted by all reconstructions is represented by the relative motions summarized in the Eurasia-North AmericaAfrica plate circuit based on marine magnetic anomalies of the Atlantic Ocean (e.g., Savostin et al., 1986; Dewey et al., 1989; Rosenbaum et al., 2002; Capitanio and Goes, 2006; Seton et al., 2012; Torsvik et al., 2012; Gaina et al., 2013; Vissers et al., 2013), which defined the area generated and consumed between Africa and Europe since the breakup of Pangaea. A critical element in Mediterranean reconstructions is the continental domain of Adria (Fig. 1). Adria is a fragment of continental crust intervening the European and African plates composed of essentially undeformed platform carbonates currently exposed on the Apulian peninsula and Gargano promontory of southern Italy, the Istrian peninsula of Croatia, and the Adige embayment of the southern Alps (Fig. 1). Adria is in a downgoing plate position relative to all surrounding mountain belts: it is overthrust by the Apennines in the west and the Dinarides-Albanides-Hellenides in the east, and although it was originally in an overriding plate position in the Alps, it became overthrust by these since Neogene time. Tectonic slices of the Adriatic upper crust are currently exposed in all circum-Adriatic mountain ranges (Stampfli and Mosar, 1999; Faccenna et al., 2001; Vai and Martini, 2001; Schmid et al., 2008; Ustaszewski et al., 2008; Bernoulli and Jenkyns, 2009; Stampfli and Hochard, 2009; Handy et al., 2010; van Hinsbergen and Schmid, 2012; Gaina et al., 2013) (Fig. 1). To the south, Adria is separated from the North African passive continental margin by oceanic lithosphere of the Ionian Basin (Catalano et al., 2001; Frizon de Lamotte et al., 2011; Gallais et al., 2011; Speranza et al., 2012).

There is no zone of intense compression between Adria and Africa, and Adria has been paleolatitudinally stable relative to Africa within paleomagnetic error bars (of typically several hundreds of kilometers) (e.g., Channell et al., 1979; Channell, 1996; Rosenbaum et al., 2004; Muttoni et al., 2013). Because the motion of Adria relative to Europe would be the best boundary condition to reconstruct the central Mediterranean kinematic history since the Mesozoic, it is crucial to reconstruct any past relative motions between Adria and Africa. Different approaches to this end, however, led to contrasting results. The Ionian Basin's sea floor is widely regarded as Mesozoic (e.g., Catalano et al., 2001; Frizon de Lamotte et al., 2011; Gallais et al., 2011; Schettino and Turco, 2011; Speranza et al., 2012), implying a semirigid connection between Adria and Africa since that time. Eastward increasing Neogene shortening in the Alps (Schönborn, 1999; Schmid et al., 2013), however, has been used to infer a Neogene $\sim 20^{\circ}$ counterclockwise (ccw) rotation of Adria relative to Eurasia (Ustaszewski et al., 2008), but only $\sim 2^{\circ}$ of which can be accounted for by Africa-Europe plate motion. Based on this kinematic model, therefore, Adria

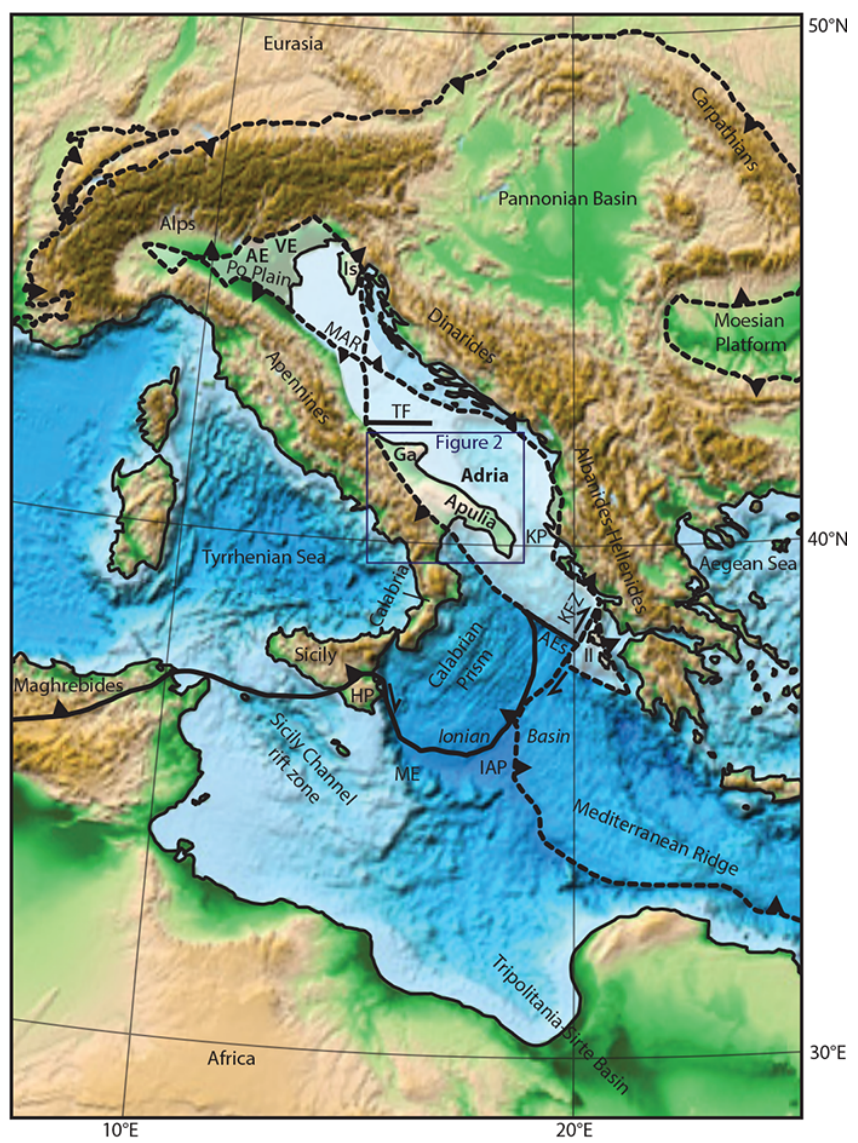

Figure 1. Regional tectonic map of the Mediterranean region. AE Adige embayment; AEs - Apulian escarpment; Ga - Gargano; HP - Hyblean Plateau; IAP - Ionian Abyssal Plain; II - Ionian Islands; Is - Istria; KFZ - Kefalonia Fault Zone; KP - Karaburun Peninsula; MAR - Mid-Adriatic Ridge; ME - Malta escarpment; TF - Tremiti fault.

must have been decoupled from Africa during the Neogene. GPS measurements suggest that, at present, Adria moves in a northeastward motion relative to Africa (D'Agostino et al., 2008). These present-day kinematics are consistent with a northeastward motion of Adria versus Africa of $40 \mathrm{~km}$ over the past $4 \mathrm{Myr}$ inferred from kinematic reconstruction of the Aegean region (van Hinsbergen and Schmid, 2012). Conversely, Wortmann et al. (2001) argued for a Cenozoic $8^{\circ}$ clockwise (cw) rotation of Adria versus Africa to avoid overlaps of Adria with Eurasia in pre-Cenozoic reconstructions, and Dercourt et al. (1986) postulated a $30^{\circ} \mathrm{ccw}$ rotation of Adria relative to Africa between 130 and $80 \mathrm{Ma}$, assuming a Cretaceous opening of the Ionian Basin.

Paleomagnetic data can provide useful quantitative constraints on the vertical axis rotation history of Adria. However, published results from Adria's sedimentary cover yielded contrasting interpretations, involving (i) no rotation (Channell and Tarling, 1975; Channell, 1977), and assuming this, paleomagnetic data from Adria have been used to 
infer the African Apparent Polar Wander Path (APWP) for particularly Early to Middle Mesozoic times (Muttoni et al., 2005, 2013; Channell et al., 2010) (ii) $20^{\circ} \mathrm{cw}$ rotation since $30 \mathrm{Ma}$ (Tozzi et al., 1988), (iii) $20^{\circ} \mathrm{ccw}$ rotation since the Late Cretaceous (Márton and Nardi, 1994), or (iv) more complex models where a $20^{\circ} \mathrm{ccw}$ Early-Late Cretaceous rotation was followed by a Late Cretaceous-Eocene $20^{\circ} \mathrm{cw}$ rotation and a post-Eocene $30^{\circ} \mathrm{ccw}$ rotation (Márton et al., 2010).

In this paper, we present a new paleomagnetic study of the Lower Cretaceous to Upper Miocene stratigraphy of the Apulian carbonate platform (southern Italy). We compare our results to and integrate these with published data sets, and evaluate the range of paleomagnetically permissible rotations values in terms of their kinematic consequences for central Mediterranean region reconstructions.

\section{Geological setting}

Prior to the onset of Africa-Europe convergence in the MidMesozoic, Adria was much larger continent stretching from the Italian Alps to Turkey (Vlahović et al., 2005). Gaina et al. (2013) introduced the term "Greater Adria" for the whole continental lithosphere including many Mesozoic intracontinental rift basins and platforms that are now incorporated in the surrounding fold-thrust belts and that existed between the Vardar ocean (or Neotethys) and the Ionian Basin.

Greater Adria was separated from Eurasia in the northeast by the Triassic Vardar, or Neotethys Ocean (Schmid et al., 2008; Stampfli and Hochard, 2009; Gaina et al., 2013), and in the north and west by the Jurassic Piemonte-Ligurian ocean, or Alpine Tethys Ocean (e.g., Frisch, 1979; Favre and Stampfli, 1992; Rosenbaum and Lister, 2005; Handy et al., 2010; Vissers et al., 2013). To the south the Ionian Basin separated Adria from Africa (Fig. 1). Adria's conjugate margin across the Ionian Basin is likely the Hyblean Plateau of Sicily bounded to the east by the Malta escarpment (Catalano et al., 2001; Chamot-Rooke and Rangin, 2005; Speranza et al., 2012).

Before the Calabrian subduction zone retreated away from Sardinia in the late Miocene (Faccenna et al., 2001, 2004; Cifelli et al., 2007; Rosenbaum et al., 2008), the Ionian Basin extended farther to the northwest. This oceanic lithosphere was at least Jurassic in age, as evidenced by off-scraped sediments now exposed in Calabria (Bonardi et al., 1988). The modern Ionian Basin is floored by a $>5 \mathrm{~km}$ thick sequence of sediments, which in the west have been thrust in response to subduction below Calabria (the Calabrian accretionary prism), and in the east in response to subduction below the Aegean region (the "Mediterranean ridge") (e.g., Finetti, 1985; Reston et al., 2002; Minelli and Faccenna, 2010; Gallais et al., 2011; Speranza et al., 2012). The Ionian Abyssal Plain is the only relatively undeformed portion that serves as the foreland of the central Mediterranean subduction systems (Hieke et al., 2006; Gallais et al., 2011;
Speranza et al., 2012). Given the crustal thickness of 7-9 km (Chamot-Rooke and Rangin, 2005) and very low heat flow (Pasquale et al., 2005), this ocean floor is likely an old remnant of the Neotethys Ocean (e.g., Gallais et al., 2011; Speranza et al., 2012). The age of the Ionian Basin has been estimated to range from late Paleozoic to Cretaceous (Sengör et al., 1984; Dercourt et al., 1986; Robertson et al., 1991; Stampfli and Borel, 2002; Golonka, 2004; Frizon de Lamotte et al., 2011; Gallais et al., 2011; Schettino and Turco, 2011), with the most recent suggestion giving a Late Triassic age (Speranza et al., 2012).

Despite the uncertainties on the opening age and direction (NE-SW according to Chamot-Rooke and Rangin, 2005, and Speranza et al., 2012, or NW-SE according to Frizon de Lamotte et al., 2011, and Gallais et al., 2011), there is general agreement that the Ionian Abyssal Plain has not been strongly deformed since the Middle Mesozoic. Minor late Miocene inversion was associated with only a few kilometers of shortening (Gallais et al., 2011). The Malta escarpment gently dips towards the basin floor, and has not been reactivated since the Mesozoic except in the northwest. There, the escarpment was used since Pliocene times as a subduction transform edge propagator (STEP) fault (Govers and Wortel, 2005), accommodating Calabrian trench retreat (Argnani and Bonazzi, 2005). Late Miocene and younger NE-SW extension, however, has been documented within the African passive margin, forming the $\sim 140 \mathrm{~km}$ wide Sicily Channel rift zone (Argnani, 2009) between Sicily and the Tunisian coast (Fig. 1). This rift system is associated with up to $\sim 40 \%$ crustal thinning and contains active rift-related volcanoes (Civile et al., 2008). The dimension of the rifted zone and the crustal attenuation may indicate some tens of kilometers of extension. This system connects southeastward to the Sirte and Tripolitania basins of Libya (Capitanio et al., 2011) and was interpreted to result from renewed late Miocene and younger NE-SW extension between Adria (and the Ionian Basin) and Africa. This extension was likely caused by slabpull forces of the subducting African plate (Argnani, 1990; Goes et al., 2004; Civile et al., 2010; Capitanio et al., 2011; Belguith et al., 2013).

Our study area, the Apulian carbonate platform, hereafter called "Apulia" (Fig. 2), is part of Adria and lies in the Plio-Pleistocene foreland of the Apennine fold-thrust belt to the west (D'Argenio et al., 1973). Recent NE-SW, lowmagnitude extension evident from Apulia (Fig. 2) is interpreted to result from flexural bending of the downgoing Adriatic lithosphere into the Apennine subduction zone (Doglioni et al., 1994; Argnani et al., 2001). To the northeast, Apulia borders the Adriatic Sea, which represents the late MioceneQuaternary foredeep of the Dinarides-Albanides-Hellenides belt (de Alteriis, 1995; Argnani et al., 1996; Bertotti et al., 2001; Argnani, 2013). The southwestern margin of Apulia appears to constitute a passive margin of the Ionian Basin in a narrow segment between the Calabrian prism and the Mediterranean ridge along the Apulian escarpment (Finetti, 


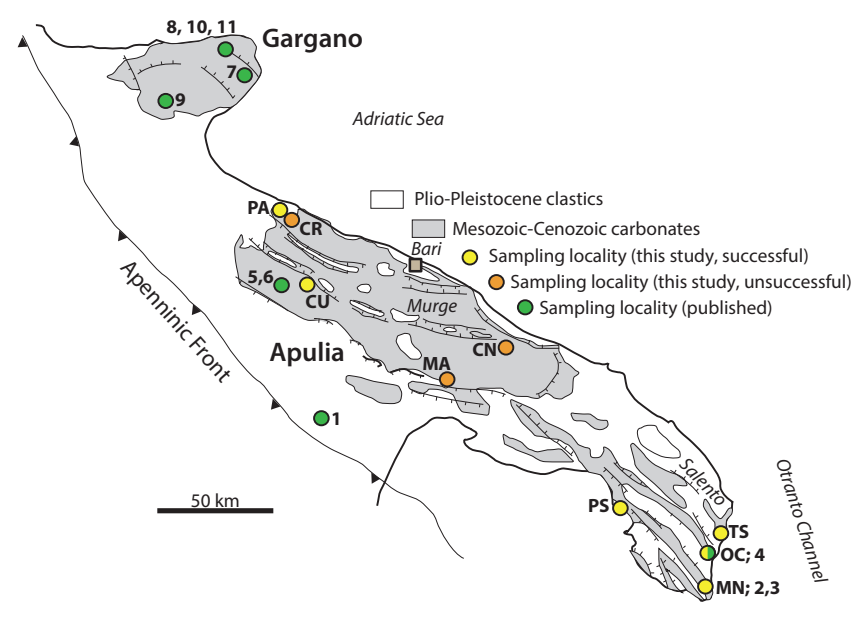

Ionian Sea

Figure 2. A simplified geological map of the exposed Apulian foreland (Apulia, southern Italy) indicating our new as well as previously published paleomagnetic sampling sites (modified from Pieri et al., 1997). Numbers and codes correspond to sites listed in Table 1 .

1985), where accumulation of sediment since the Mesozoic has compensated for the thermal subsidence of the oceanic lithosphere (Channell et al., 1979; Ricchetti et al., 1998).

The northern margin of the platform is exposed on the Gargano promontory that was located close to the northeastern transition of Apulia toward the adjacent Adriatic Basin (Bosellini et al., 1999b; Graziano et al., 2013; Santantonio et al., 2013). The Adriatic Basin, from which the present-day Adriatic Sea roughly inherited the location, was a Jurassic deep-water continental rift basin that continued northwestward into the Umbria-Marche basin, now incorporated in the Apennine fold-thrust belt, and southeastward into the Ionian zone, which is now part of the Hellenides-Albanides and should not be confused with the previously mentioned oceanic Ionian Basin, located on the opposite side of Apulia (Zappaterra, 1990, 1994; Flores et al., 1991; Mattavelli et al., 1991; Grandic et al., 2002; Picha, 2002; Fantoni and Franciosi, 2010). Basin-transition units of Apulia have in the Pliocene and younger times become incorporated in the pre-Apulian zone of western Greece, exposed on the Ionian Islands, which became separated from Apulia along the Kefalonia Fault Zone (Underhill, 1989; van Hinsbergen et al., 2006; Royden and Papanikolaou, 2011; Kokkalas et al., 2012).

To the north of Apulia, in the central Adriatic Sea, the fronts of the external Dinarides and Apennines converge producing the Mid-Adriatic Ridge (Fig. 1). Along this structure, the Adriatic Sea floor is cut by Neogene NW-SE striking thrusts, some of which invert Mesozoic extensional structures (Grandic et al., 2002; Scrocca, 2006; Scisciani and Calamita, 2009; Fantoni and Franciosi, 2010; Kastelic et al., 2013). South of the Mid-Adriatic Ridge, several E-W to NE-
SW striking strike-slip structures have been suggested to dissect the Adriatic Sea floor. The exact location and kinematics of these structures is controversial, but is primarily considered dextral based on seismicity, low-resolution seismic lines, and GPS velocities (see below). As a result, three main deformation zones, alternative to each other, were called into consideration to decouple northern and southern Adria. The first one is the Pescara-Dubrovnik line (corresponding to the Mid-Adriatic Ridge in Fig. 1), whose presence was hypothesized by Gambini and Tozzi (1996), and that roughly corresponds to a segment of the boundary that, according to Oldow et al. (2002), borders two fragments of Adria with different GPS velocity. The second one is the Tremiti Line of Finetti (1982) or the Tremiti Structure of Andre and Doulcet (1991), whose presence is evident from both its seismicity (Favali et al., 1990, 1993) and sea-floor structure (Argnani et al., 1993). According to Doglioni et al. (1994) and Scrocca (2006), this dextral lithospheric structure segments Adria in order to accommodate a differential slab retreat, and according to Festa et al. (2014), its subsurface expressions were enhanced by salt tectonics; (iii) finally, also the Mid-Adriatic Ridge was interpreted to be a boundary between two different sectors of Adria (Scisciani and Calamita, 2009), assuming that some structural highs of the external Dinarides (i.e., the Palagruza High of Grandic et al. (2002) represent the southward prosecution of the same ridge in the eastern Adriatic Sea.

Apulia was considered an isolated carbonate platform that developed away from emerged continents (D'Argenio et al., 1973) until the discovery of dinosaur footprints that suggested the presence of some continental bridges between Apulia and other coeval exposed regions in Late Jurassic to Early Cretaceous time (e.g., Bosellini, 2002). During the Mesozoic, shallow-water carbonate deposition was able to compensate for the regional subsidence, and led to the accumulation of a stratigraphic succession up to $6000 \mathrm{~m}$ thick (Ricchetti et al., 1998). The succession, whose Cretaceous interval is widely exposed, consists mainly of dolomitic and calcareous rocks (Ricchetti, 1975). In the Murge area (Fig. 2), where its age has been best constrained (Spalluto et al., 2005; Spalluto and Caffau, 2010; Spalluto, 2011), the succession forms a monocline dipping gently towards the SSW, thus exposing younger rocks from NNE to SSW (Ciaranfi et al., 1988) (Fig. 2). This monoclinal succession is deformed by gentle undulations and steep normal and transtensional faults with an overall NW-SE orientation (Festa, 2003). The southernmost part of the exposed Apulia (i.e., the edge of the Salento peninsula facing the Otranto Channel, Fig. 2) represents the position of the Mesozoic platform margin (Bosellini et al., 1999b). It probably sharply passed to a southern intraplatform pelagic basin, recognized in the subsurface of the submerged Apulia (Del Ben et al., 2010). Post-Cretaceous carbonate rocks cropping out along this Salento margin show well-preserved tens of meters thick clinoforms, i.e slope deposits that formed along 
PA 6a

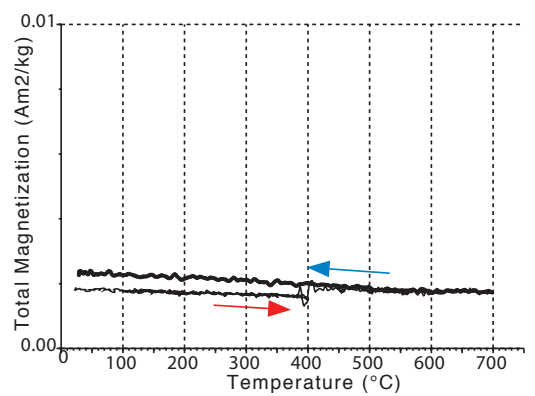

PS 5.1

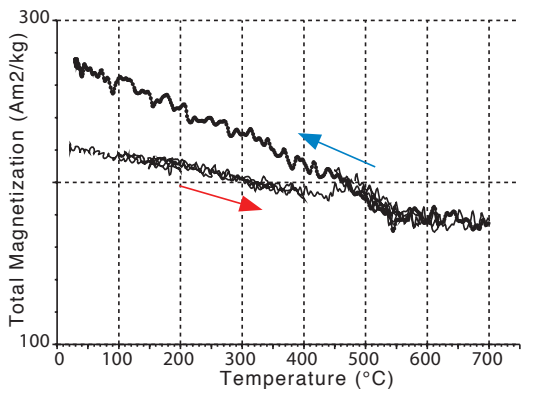

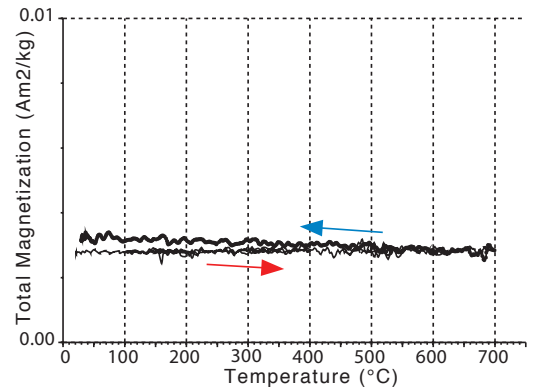

Figure 3. Thermomagnetic curves measured on a Curie balance (Mullender et al., 1993) for representative samples. Arrows indicate heating (red) and cooling (blue).

and rework rocks of the old Apulia margin (Bosellini et al., $1999 \mathrm{~b})$. These slope deposits reach up to $25 / 30^{\circ}$ of primary non-tectonic dip (Tropeano et al., 2004; Bosellini, 2006).

\section{Paleomagnetic sampling, analysis and results}

\subsection{Sampling and laboratory treatment}

We collected 456 samples from nine localities covering the Cretaceous and Cenozoic carbonate stratigraphy of Apulia. Cores samples were collected with a gasoline-powered motor drill, and their orientation was measured with a magnetic compass.

The samples were measured at the Paleomagnetic Laboratory Fort Hoofddijk of Utrecht University, the Netherlands. The nature of the magnetic carriers was investigated for representative samples using an in-house developed horizontal translation-type Curie balance, with a sensitivity of $5 \times 10^{-9} \mathrm{Am}^{2}$ (Mullender et al., 1993). Approximately $60 \mathrm{mg}$ of powder obtained from each sample was subjected to stepwise heating-cooling cycles up to $700{ }^{\circ} \mathrm{C}$.

For each locality, 8 to 10 samples were selected as pilot samples, and of each sample two specimens were retrieved for both thermal (TH) and alternating field (AF) demagnetization. AF demagnetization and measurement of the remanence were carried out using an in-house developed robotized sample handler coupled to a horizontal pass-through $2 \mathrm{G}$ Enterprises DC SQUID cryogenic magnetometer (noise level $1 \times 10^{-12} \mathrm{Am}^{2}$ ) located in a magnetically shielded room (residual field $<200 \mathrm{nT}$ ). Samples were demagnetized by stepwise AF treatment (alternating field steps: 5, 8, 12, 15, $20,25,30,35,40,45,50,60,70,80$ and $100 \mathrm{mT}$ ). Thermal demagnetization was performed in a magnetically shielded oven using variable temperature increments up to $500^{\circ} \mathrm{C}$. After each heating step the remanence was measured with a 2G Enterprises horizontal 2G DC SQUID cryogenic magnetometer (noise level $3 \times 10^{-12} \mathrm{Am}^{2}$ ).

Thermal demagnetization treatment demonstrated to be more effective for the sampled rocks as it provided more sta- ble demagnetization diagrams than the AF technique. The remaining samples of each locality were therefore thermally demagnetized.

Demagnetization diagrams were plotted on orthogonal vector diagrams (Zijderveld, 1967), and the characteristic remanent magnetization (ChRM) was isolated via principal component analysis (Kirschvink, 1980). Samples with a maximum angular deviation (MAD) larger than $15^{\circ}$ were rejected from further analysis. Because secular variation of the geomagnetic field induces scatter in paleomagnetic directions whose distribution gradually becomes more ellipsoidal towards equatorial latitudes (Creer et al., 1959; Tauxe and Kent, 2004), we calculated site mean directions using Fisher (1953) statistics on virtual geomagnetic poles (VGPs) following procedures described in Deenen et al. (2011). At each locality a $45^{\circ}$ cutoff was applied to the VGPs (Johnson et al., 2008). The results were then filtered by the paleomagnetic quality criteria of the $\mathrm{N}$-dependent reliability envelope of Deenen et al. (2011). Mean values and statistical parameters are listed in Table 1.

\subsection{Results}

Curie balance results are noisy because of the very low intensities of these carbonates, and do not reveal meaningful information about the carriers of the remanence. Upon close inspection it can be seen that some new magnetic mineral is created upon heating, just above $400^{\circ} \mathrm{C}$. This points to the presence of minor amounts of pyrite converted to magnetite. The cooling curves are higher than the heating curves, confirming that new magnetic minerals were created that were not fully removed upon heating to $700^{\circ} \mathrm{C}$ (Fig. 3).

As a result of very low Natural Remanent Magnetization (NRM) intensities, nearly $30 \%$ of the demagnetized specimens (167) show an erratic demagnetization pattern yielded no interpretable directions. Nevertheless, a total of 298 demagnetized specimens show a weak but stable and measurable remanence. In general, the lowest temperature steps (or AF steps) show a viscous or present-day overprint (Fig. 4). 

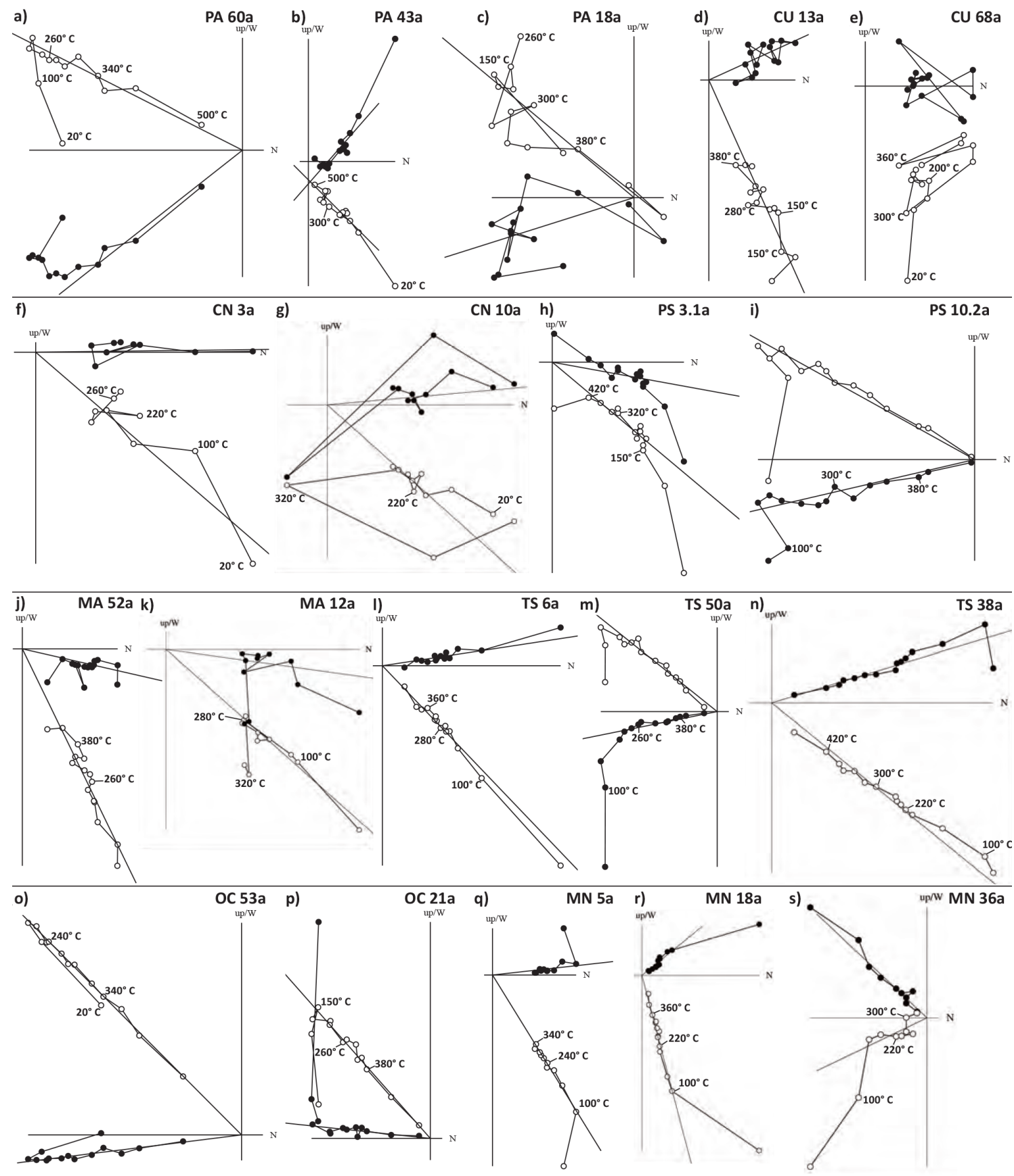

Figure 4. Orthogonal vector diagrams (Zijderveld, 1967), showing representative demagnetization diagrams for all sampled sites. Except for OC, TS and MN all sites are in tilt-corrected coordinates. Closed (open) circles indicate the projection on the horizontal (vertical) plane.

After removing this overprint, the characteristic remanent magnetization (ChRM) directions can be interpreted. Most specimens show interpretable results up to temperatures of approximately $400-450^{\circ} \mathrm{C}$. Above this temperature intensities become too low or spurious magnetization occurs that hampers any further interpretation (e.g., Fig. 4g). Of the more successful demagnetization diagrams, we use 8 to 10 succes- sive temperature steps for the ChRM directions determined by principal component analysis.

\subsubsection{Locality Petraro quarry (PA)}

The Petraro quarry (PA) is located in NE Murge (Fig. 2). This section shows the oldest part of the Calcare di Bari Formation cropping out in the Murge area and consists of a well-bedded, $55 \mathrm{~m}$ thick, shallow-water carbonate succession 

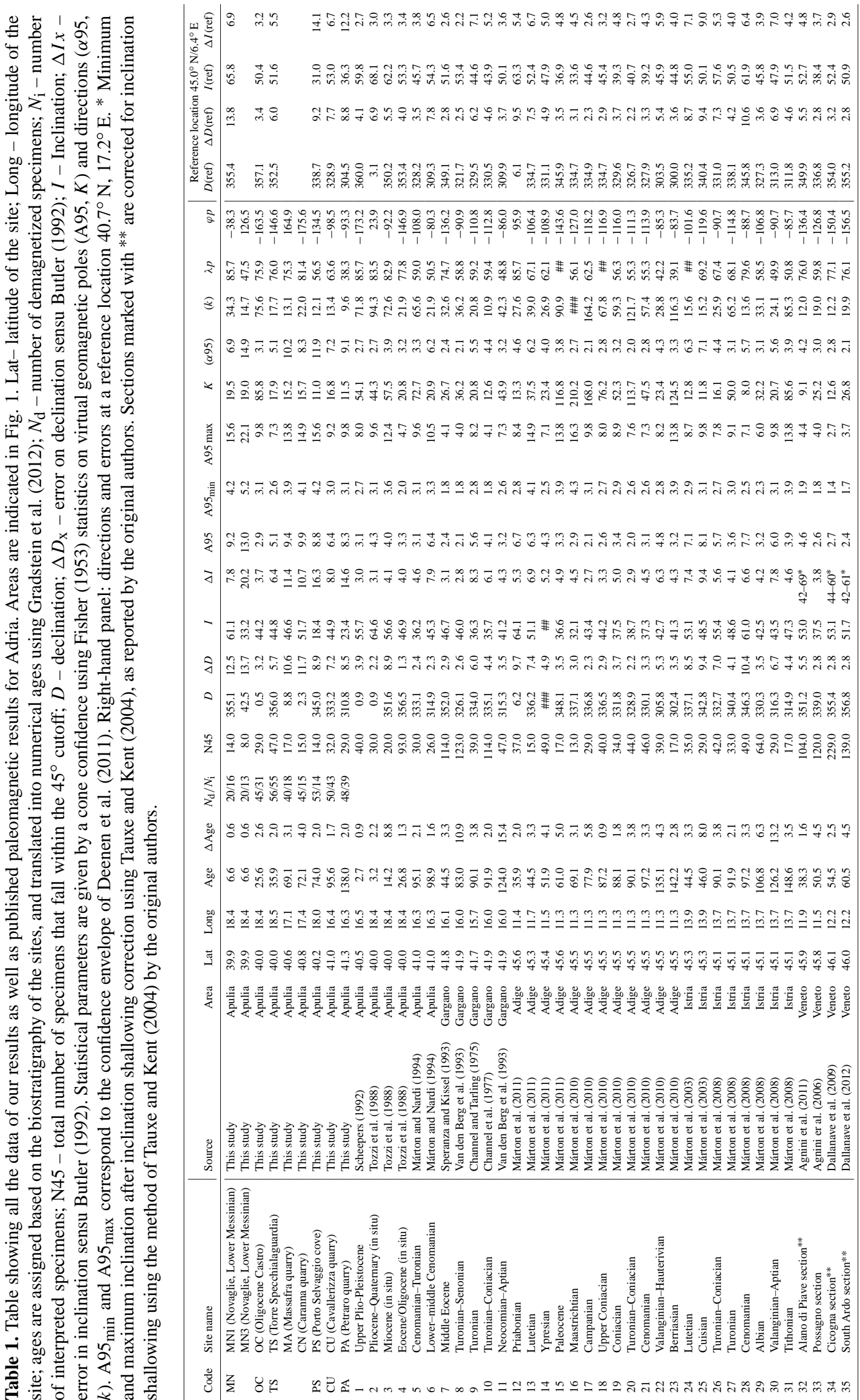
in which few-decimeter-thick carbonate beds are irregularly alternated with a few-meter-thick dolomitic beds (LupertoSinni and Masse, 1984). Carbonate lithofacies are made up of biopeloidal wackestones/packstones and microbial bindstones with rare intercalations of biopeloidal and oolitic grainstones interpreted as formed in inner shelf peritidal environments. Dolomites consist of an anhedral or subhedral mosaic of dolomitic crystals, which totally or partly replaced the carbonate precursor. Based on the study of the microfossiliferous assemblage of PA (mostly benthic foraminifers and calcareous algae), Luperto-Sinni and Masse (1984) assign this succession to the Valanginian $(\sim 140-136 \mathrm{Ma}$; according to the geological timescale of Gradstein et al., 2012). We sampled a $10 \mathrm{~m}$ thick interval of this section and avoided dolomitic beds.

The NRM intensity of these samples is very low (30$300 \mu \mathrm{A} \mathrm{m}^{-1}$ ), and stable ChRMs were isolated for only 39 specimens at temperature steps between 220 and $500^{\circ} \mathrm{C}$ (Fig. 4a-c). The ChRMs show both normal and reverse polarities, and yield a positive reversal test (Johnson et al., 2008; McFadden and McElhinny, 1990) (classification C; $\gamma=15.9<\gamma_{c}=19.5$ ). The distribution of the ChRMs satisfies the quality criteria of representing Paleo-Secular Variation (PSV) (i.e., A95 min $_{2}$ A95 < A95 $\max$; Deenen et al. (2011). The tilt-corrected mean ChRM direction for this locality after a fixed $45^{\circ}$ cutoff is $D \pm \Delta D=130.8 \pm 8.5^{\circ}$, $I \pm \Delta I=-23.4 \pm 14.6^{\circ}\left(N=29, K=11.5, \mathrm{~A} 95=10.9^{\circ}\right)$ (Table 1 and Fig. 5).

\subsubsection{Locality Casa Rossa quarry (CR)}

The Casa Rossa quarry (CR) is a large limestone quarry in the NE Murge area (Fig. 2), located SW of Trani. The outcropping section consists of a well-bedded, more than $40 \mathrm{~m}$ thick, shallow-water carbonate succession. Similarly to the Petraro quarry, carbonate beds consist of biopeloidal wackestones/packstones and microbial bindstones showing evidence of desiccation features (mud cracks and birdseyes) suggesting inner shelf peritidal environments. Interbedded with the carbonate lithofacies, there are few-millimeter-thick green shale intercalations interpreted as paleosols. Based on the study of the microfossiliferous assemblage of CR, Luperto-Sinni and Masse (1984) assign this succession to the Barremian to lower Aptian ( 129-121 Ma). We sampled a stratigraphic thickness of $20 \mathrm{~m}$ in the lower part of the outcropping succession. The low intensity of these rocks $\left(5-100 \mu \mathrm{A} \mathrm{m}^{-1}\right)$ did not allow us to obtain high-quality remanence components because of high MAD values. The distribution of the isolated ChRMs is highly scattered, failing all the adopted quality criteria (Fig. 5). The locality is therefore not considered for further analyses.

\subsubsection{Locality Cavallerizza quarry (CU)}

The Cavallerizza quarry (CU) is located in the western Murge area (Fig. 2), close to the town of Ruvo di Puglia. The outcropping section shows rudist biogenic beds, late Cenomanian in age $(\sim 98-94 \mathrm{Ma})$, belonging to the uppermost part of the Calcare di Bari Fm (Iannone and Laviano, 1980). Rudist beds are topped by a horizon of green clays, $1 \mathrm{~m}$ thick, interpreted as a paleosol, which marks a regional unconformity covering the whole Turonian $(\sim 94$ $90 \mathrm{Ma})$. Peritidal limestones of the Calcare di Altamura Fm, Coniacian-Santonian in age $(\sim 90-83.5 \mathrm{Ma})$, overlie green shales and mark the recovery of carbonate marine sedimentation after the Turonian subaerial exposure. A total of 43 samples were collected from the lower, $15 \mathrm{~m}$ thick, greybrown rudist limestones of the Calcare di Bari Fm. According to Laviano et al. (1998), upper Cenomanian rudist beds cropping out in the Ruvo area record the progradation of a rudist-inhabited margin into a shallow intraplatform basin. Samples are characterized by generally low intensities (10-290 $\mu \mathrm{A} \mathrm{m}^{-1}$ ), but show interpretable demagnetization diagrams (Fig. 4d-e). The mean tilt-corrected direction after applying a $45^{\circ}$ cutoff to the ChRM distribution is $D \pm \Delta D=333.2 \pm 7.1^{\circ}, I \pm \Delta I=44.9 \pm 8.0^{\circ}(N=32$, $\left.K=16.8, \mathrm{~A} 95=10.2^{\circ}\right)($ Table 1 and Fig. 5$)$. The VGP scatter for this site is consistent with that expected from PSV (A95 $5_{\min }<$ A95 $<$ A95 $5_{\max }$ ).

\subsubsection{Locality Caranna quarry $(\mathrm{CN})$}

The Caranna quarry (CN) is located in SE Murge (Fig. 2), close to the town of Cisternino. The outcropping section consists of an about $20 \mathrm{~m}$ thick succession of thin-bedded pelagic chalky limestones (microbioclastic mudstones to wackestones) containing planktonic foraminifers and calcispheres. According to Pieri and Laviano (1989) and LupertoSinni and Borgomano (1989), these deposits formed in relatively deep-water, distal slope environments in late Campanian to early Maastrichtian times ( 78-69 Ma). All 45 samples were collected from the lower part of the outcropping succession. Only $30 \%$ of the analyzed specimens yielded interpretable demagnetization diagrams because of the low intensity of the NRM $\left(8-34 \mu \mathrm{A} \mathrm{m}^{-1}\right)$. Stable ChRMs were isolated at low temperatures commonly not exceeding $280^{\circ} \mathrm{C}$ (Fig. $4 \mathrm{f}-\mathrm{g}$ ), and their distribution provided a mean value of $D \pm \Delta D=2.3 \pm 11.8^{\circ}, I \pm \Delta I=51.7 \pm 10.7^{\circ}(N=15$, $K=15.7$, A95 $\left.=9.9^{\circ}\right)($ Table 1 and Fig. 5). Although the distribution of the ChRMs reflects a PSV-induced scatter, the obtained mean direction is not statistically different from the present-day field direction (PDF; Fig. 5) and is inconsistent with the expected Cretaceous inclinations. It is very likely that a recent magnetic overprint affected this site, and the obtained results are not considered further. 

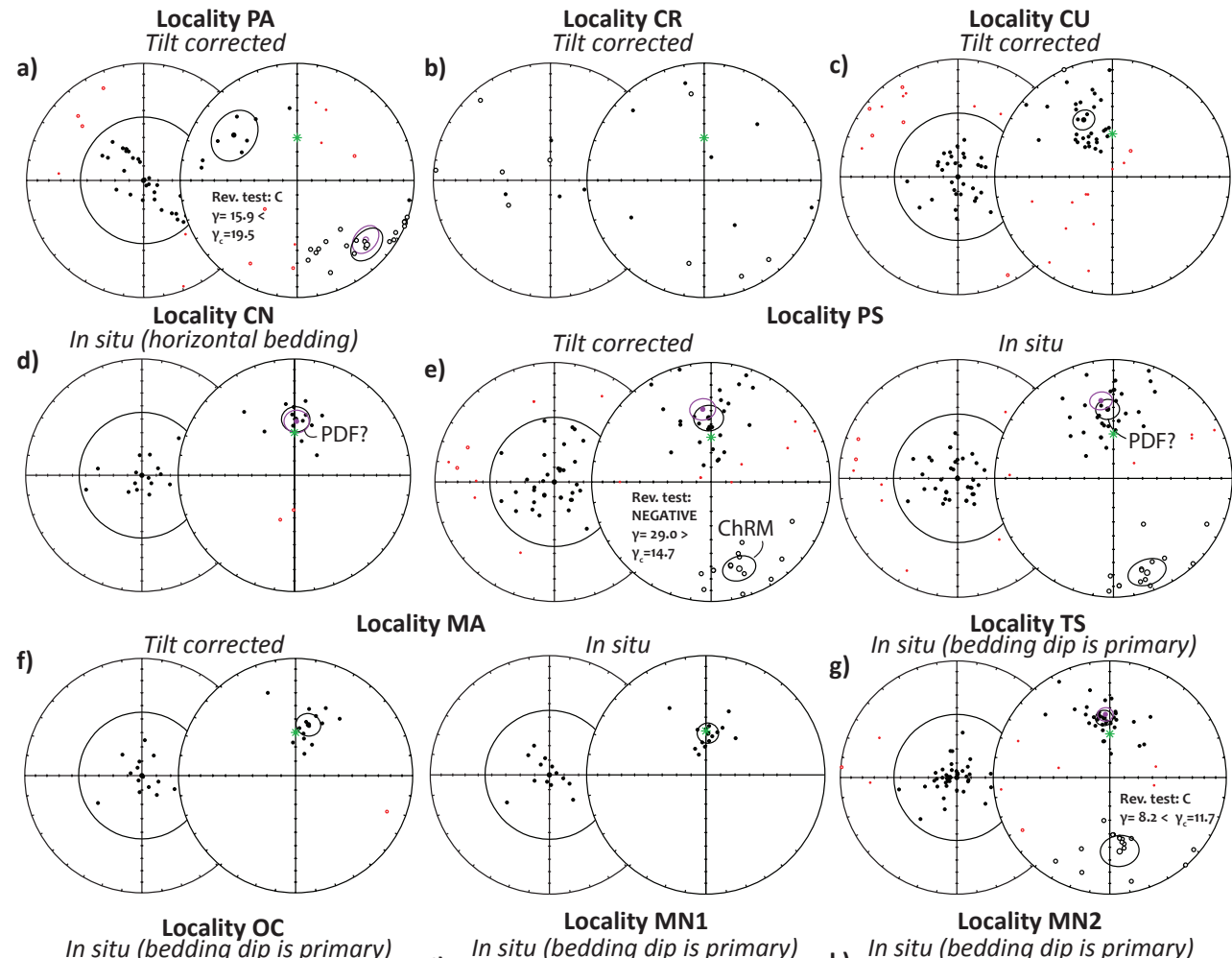

Locality TS
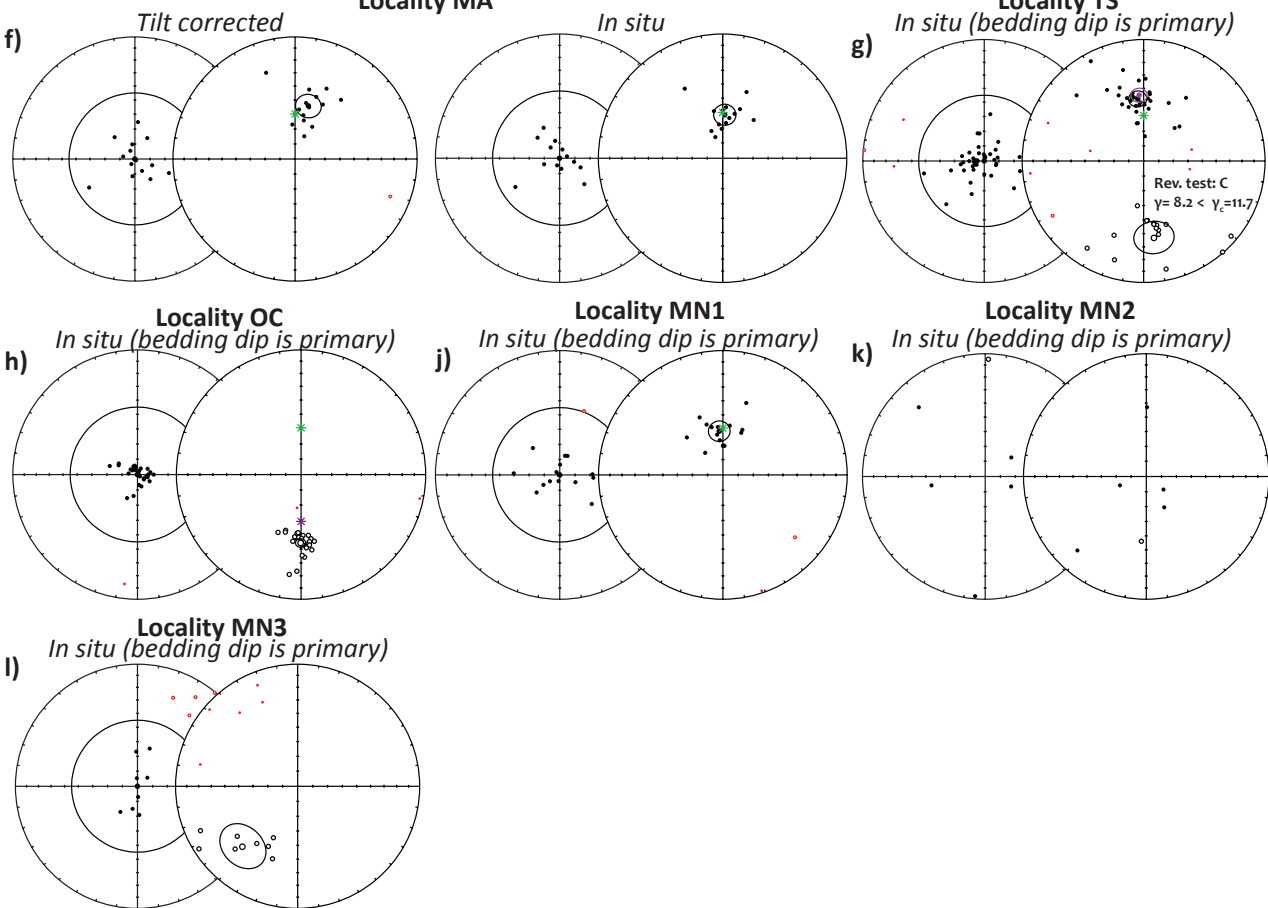

Figure 5. Equal area projections of the VGP (left) and ChRM directions (right) of all sites in both in situ and tilt-corrected coordinates. Open (closed) symbols correspond to the projection on the upper (lower) hemisphere. Large dots in the ChRM plots indicate the mean direction and relative cone of confidence $(\alpha 95)$. Red (small) dots indicate the individual directions rejected after applying a $45^{\circ}$ cutoff. Green asterisk $\left(^{*}\right)$ indicates the present-day geocentric axial dipole (GAD) field direction at the sampled location. Sites TS, OC, and MN were sampled in sediments with a primary bedding attitudes, and should be considered in in situ coordinates.

\subsubsection{Locality Porto Selvaggio cove (PS)}

The succession of the Porto Selvaggio cove (PS) crops out in western Salento. It mostly consists of upper Campanian chalky limestones ( $\sim 78-72 \mathrm{Ma})$, slightly dipping to the SE, overlying subhorizontal shallow marine limestones and dolomites (Reina and Luperto-Sinni, 1994a). According to Mastrogiacomo et al. (2012) chalky limestones sampled in this study formed in an intraplatform basin and record the evidence of a synsedimentary tectonic activity, as shown by the occurrence of two horizons of soft-sediment deformation structures (slumps). Out of the 52 demagnetized specimens, 48 yielded interpretable diagrams for the calculation of the ChRMs (Fig. 4h-i). The NRM of those samples is characterized by relatively low intensities $\left(10-2000 \mu \mathrm{A} \mathrm{m}^{-1}\right)$ and both normal and reversed ChRMs that did not pass the reversal test $\left(\gamma=29>\gamma_{c}=14.7\right)$ (McFadden and McElhinny, 1990). The mean normal polarity ChRM shows, after a fixed $45^{\circ}$ cutoff, a $D \pm \Delta D=357.7 \pm 10.3^{\circ}, I \pm \Delta I=45.4 \pm 11.4^{\circ}$ $\left(N=23, K=10.1, \mathrm{~A} 95=9.2^{\circ}\right)($ Table 1 , Fig. 5$)$, very close 
to the present-day field, and likely the result of a recent overprint. The reverse polarity ChRMs yield a mean value that is statistically different from the present-day field direction $\left(D \pm \Delta D=165.0 \pm 8.9^{\circ}, I \pm \Delta \mathrm{I}=-18.4 \pm 16.2^{\circ}, N=14\right.$, $K=21.6$, A95 $=8.8^{\circ}$; see Table 1 ). The distribution of the reverse polarity ChRMs satisfies our criteria. Accordingly, only the reversed polarity ChRM is used for further analyses.

\subsubsection{Locality Massafra (MA)}

This locality was sampled from a road cut close to the town of Massafra in the south of Murge (Fig. 2). We sampled a $15 \mathrm{~m}$ thick stratigraphic interval mostly comprising well-bedded white to light-brown shallow-water limestones with a Maastrichtian age (72-66 Ma) (Reina and Luperto-Sinni, 1994b). Sampled limestones mostly consist of peritidal, mud-supported, biopeloidal mudstones and wackestones showing a benthic microfossiliferous assemblage (mostly benthic foraminifers and ostracodes). The NRM intensity in those samples is relatively low $\left(0.08-6 \mathrm{~mA} \mathrm{~m}^{-1}\right)$, and only 18 samples yielded interpretable demagnetization diagrams (Fig. 4). The mean direction of the isolated ChRMs in tilt-corrected coordinates is $\mathrm{D} \pm \Delta D=8.8 \pm 10.7^{\circ}, I \pm \Delta I=46.6 \pm 11.4^{\circ}$ $\left(N=17, K=15.2, \mathrm{~A} 95=9.4^{\circ}\right)$ (Table 1 and Fig. 5). Before tilt correction, this direction is not statistically different from the present-day field $\left(D \pm \Delta D=359.8 \pm 12.6^{\circ}\right.$, $\left.I \pm \Delta I=52.2 \pm 11.2^{\circ}, \quad N=17, \quad K=12.4, \quad \mathrm{~A} 95=10.5^{\circ}\right)$ and is probably the effect of a recent overprint. Accordingly, this site is not considered for further analyses.

\subsubsection{Locality Torre Spechialaguardia (TS)}

An about $10 \mathrm{~m}$ thick succession of clinostratified breccias and bioclastic deposits was sampled at the Torre Specchialaguardia locality (TS) in eastern Salento (Fig. 2). This succession belongs to the Upper Eocene (Priabonian, 44-38 Ma) Torre Specchialaguardia Limestone Fm (Parente, 1994), which formed in a steep forereef slope onlapping a rocky Cretaceous to Eocene paleocliff (Bosellini et al., 1999b). According to Parente (1994) and Bosellini et al. (1999b), this formation is the oldest non-deformed unit in eastern Salento, and its current dip of $\sim 30^{\circ}$ to the ESE is a primary, non-tectonic orientation. A total of 56 samples yielded NRM intensities ranging between 0.15 and $3 \mathrm{~mA} \mathrm{~m}^{-1}$ and usually gave stable demagnetization diagrams characterized by curie temperatures around $420^{\circ} \mathrm{C}$ (Fig. 4l-n). The remanence displays both normal and reverse polarities that pass the reversal test (McFadden and McElhinny, 1990) (classification C, $\gamma=8.2<\gamma_{\mathrm{c}}=11.7$ ). After a fixed $45^{\circ}$ cutoff, the mean in situ ChRM direction is $D \pm \Delta D=356.0 \pm 5.6^{\circ}, I \pm \Delta I=44.8 \pm 6.3^{\circ}(N=47$, $\left.K=17.9, \mathrm{~A} 95=5.1^{\circ}\right)($ Table 1, Fig. 5), and the ChRM distribution satisfies our criteria.

\subsubsection{Locality Castro (OC)}

An about $10 \mathrm{~m}$ thick section was sampled close to the village of Castro (OC) in eastern Salento (Fig. 2). The outcropping succession consists of Upper Oligocene (Chattian, 28-23 Ma) limestones belonging to the Castro Limestone Fm (Bosellini and Russo, 1992; Parente, 1994). This unit represents a fringing reef complex and shows a very well-preserved lateral zonation of the reef subenvironments (Bosellini and Russo, 1992; Parente, 1994). The sampled section shows clinostratified bioclastic deposits belonging to the reef slope subenvironment showing no evidence of tectonic deformation (Bosellini and Russo, 1992; Pomar et al., 2014). Very low NRM intensities characterize these rocks $\left(15-180 \mu \mathrm{A} \mathrm{m}^{-1}\right)$, and stable ChRM components with maximum unblocking temperatures between 220 and $500{ }^{\circ} \mathrm{C}$ were isolated from 31 specimens (Fig. 4op). The mean ChRM direction after a fixed $45^{\circ}$ cutoff is $D \pm \Delta D=180.5 \pm 3.2^{\circ}, I \pm \Delta I=-44.2 \pm 3.7^{\circ} \quad(N=29$, $K=85.8$, A95 $=2.9^{\circ}$ ) (Table 1 and Fig. 5). The VGP distribution does not entirely satisfy our criteria, since the A95 value is lower than $\mathrm{A} 95_{\mathrm{min}}$, indicating that PSV is underrepresented. The reverse polarity of the ChRMs and their low inclinations excludes a present-day (or recent) overprint, and the underrepresentation of PSV may be the result of some averaging PSV within each limestone sample.

\subsubsection{Locality Novaglie (MN1-3)}

Three different sites belonging to the Lower Messinian succession of the Novaglie Fm were sampled within $3 \mathrm{~km}$ of each other, close to the eastern Salento coast (Fig. 2). The outcropping successions consist of in situ coral reef bioconstructions, clinostratified breccias and associated bioclastic and lithoclastic prograding slope deposits and fine-grained, bioclastic base-of-slope calcarenites. Similarly to the previous two localities, the bedding attitude in the sampled sites is most likely primary (Bosellini et al., 1999b, a, 2001; Vescogni, 2000). At each subsite 20 samples were collected from a $10 \mathrm{~m}$ thick interval. NRM intensities range between 9 and $5000 \mathrm{\mu A} \mathrm{m}^{-1}$. A total of 16, 13, and $6 \mathrm{ChRMs}$ were successfully isolated from subsite MN1, MN2, and MN3, respectively (Fig. 4q-s). Overall, the direction of the isolated ChRMs is substantially scattered, with both normal and reverse polarities. The reversal test yielded a negative result (McFadden and McElhinny, 1990); therefore, separate mean values were calculated at each subsite.

After a fixed $45^{\circ}$ cutoff, site MN1 yielded a mean paleomagnetic direction of $D \pm \Delta D=355.1 \pm 12.5^{\circ}$, $I \pm \Delta I=61.1 \pm 7.9^{\circ} \quad\left(N=14, \quad K=19.5, \quad \mathrm{~A} 95=9.2^{\circ}\right)$ (Table 1, Fig. 5). The VGP distribution passes our quality criteria. Only six specimens of MN2 yielded a poorly defined ChRM, with a dispersion well beyond our quality criteria (Fig. 5). This subsite was discarded. The large scatter of the ChRMs of subsite MN3 yields, after the $45^{\circ}$ cutoff, eight 


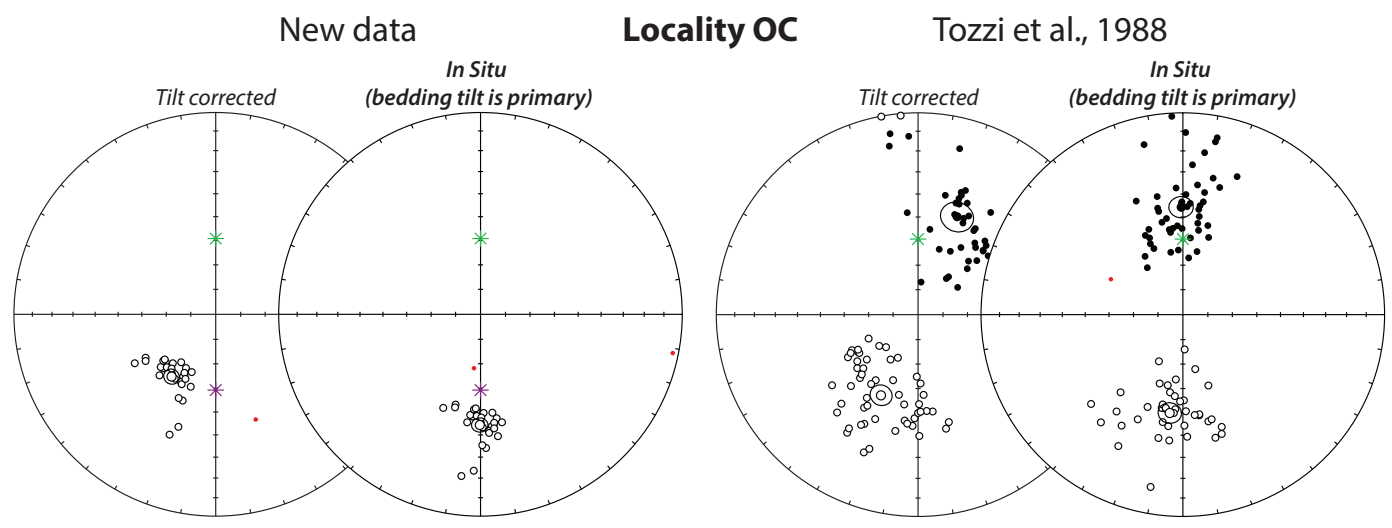

Figure 6. Equal area projections of both in situ and tilt-corrected ChRMs from our site OC (left) and from the same locality of Tozzi et al. (1988) (right), illustrating the apparent clockwise rotation that would result from a tilt correction of the bedding at this locality. The strata here have a primary dip (Fig. 7) and should be considered in in situ coordinates. Symbols are as in Fig. 5.

samples with a mean ChRM of $D \pm \Delta D=222.5 \pm 13.7^{\circ}$, $I \pm \Delta I=-33.2 \pm 20.2^{\circ} \quad\left(N=8, \quad K=19.0, \quad \mathrm{~A} 95=13.0^{\circ}\right)$ (Table 1, Fig. 5). Despite the low number of specimens, the A95 envelope passes the Deenen et al. (2011) criteria (Table 1).

\section{Discussion}

\subsection{Paleomagnetic constraints on the rotation of Adria}

Reliable paleomagnetic poles were obtained from six localities (out of nine) sampled throughout Apulia (Fig. 2). The results from three localities were discarded because the distribution of the isolated ChRMs did not match the adopted quality criteria or because of a present-day overprint. One more site (MN3), although passing the quality criteria, yielded an anomalous declination $\left(042.5 \pm 13.7^{\circ}\right)$ indicating a strong clockwise rotation, not seen in the rest of the reliable sites. The anomalous direction at site MN3 may be explained considering that the samples, collected in a forereef breccia, could represent a large fallen block within the Messinian slope deposits. Regardless of the cause of this local rotation, we consider this direction not meaningful for the analysis of the regional rotation of Adria.

The rotation of Adria and its relationship with the African plate has always been a moot point (Caporali et al., 2000; Márton et al., 2003, 2008). Our new data provide new constraints for the rotation of Adria during the Cenozoic and, more importantly, can test the robustness and reliability of the available data set.

The results of the Oligocene site OC (Fig. 2) can be compared with those obtained by Tozzi et al. (1988) from the same area. These authors interpreted the local $\sim 30^{\circ}$ eastsoutheastward bedding dip as a result of tectonic tilting, inconsistent with sedimentological studies (e.g., Tropeano et al., 2004; Bosellini, 2006), and calculated a post-Paleogene $\sim 25^{\circ} \mathrm{cw}$ rotation of Adria by restoring this bedding to the horizontal. The paleomagnetic direction should be interpreted in in situ coordinates, and our results as well as those of Tozzi et al. (1988) are coincident and indicate no or a minor counterclockwise post-Oligocene rotation of Adria with respect to Africa (Fig. 6).

To assess whether and when Adria rotated relative to Africa, we combine our results with published data from Apulia, Gargano, Istria and the Adige embayment, and compare them to the expected directions for the European and African plates calculated from the Global APWP of Torsvik et al. (2012) using a reference location of $40.7^{\circ} \mathrm{N}, 17.2^{\circ} \mathrm{E}$ (Table 1, Fig. 7). Mean paleomagnetic directions and statistical parameters from the existing database were recalculated at each site by averaging VGPs obtained through parametric bootstrap sampling using the provided mean values and statistical parameters (Table 1). This procedure overcomes the loss of information on the original data scatter that occurs when only the mean paleomagnetic direction at a given locality is computed by averaging site averages. In addition, sites with different numbers of samples should weigh differently, since large data sets provide a better representation of PSV than small data sets (see Deenen et al., 2011).

The updated paleomagnetic database is composed of 12 poles from Apulia (6 from Tozzi et al., 1988; Scheepers, 1992; Márton and Nardi, 1994, and the 6 successful poles from this study), 5 from the Gargano promontory (Channell and Tarling, 1975; Channell, 1977; Vandenberg, 1983; Speranza and Kissel, 1993), 12 poles from the Adige embayment (Márton et al., 2010, 2011) and 4 poles from the Veneto area in northern Italy (Agnini et al., 2006, 2011; Dallanave et al., 2009,2012 ), and 8 poles from the Istrian peninsula of Croatia (Márton et al., 2003, 2008) (Table 1). At 6 out of 12 localities from the Adige embayment, PSV is underrepresented (A95 < A95 $5_{\min }$; Table 1). We assume that this is a result of within-sample averaging due to low sedimentation rates and have included these sites in our analysis. 

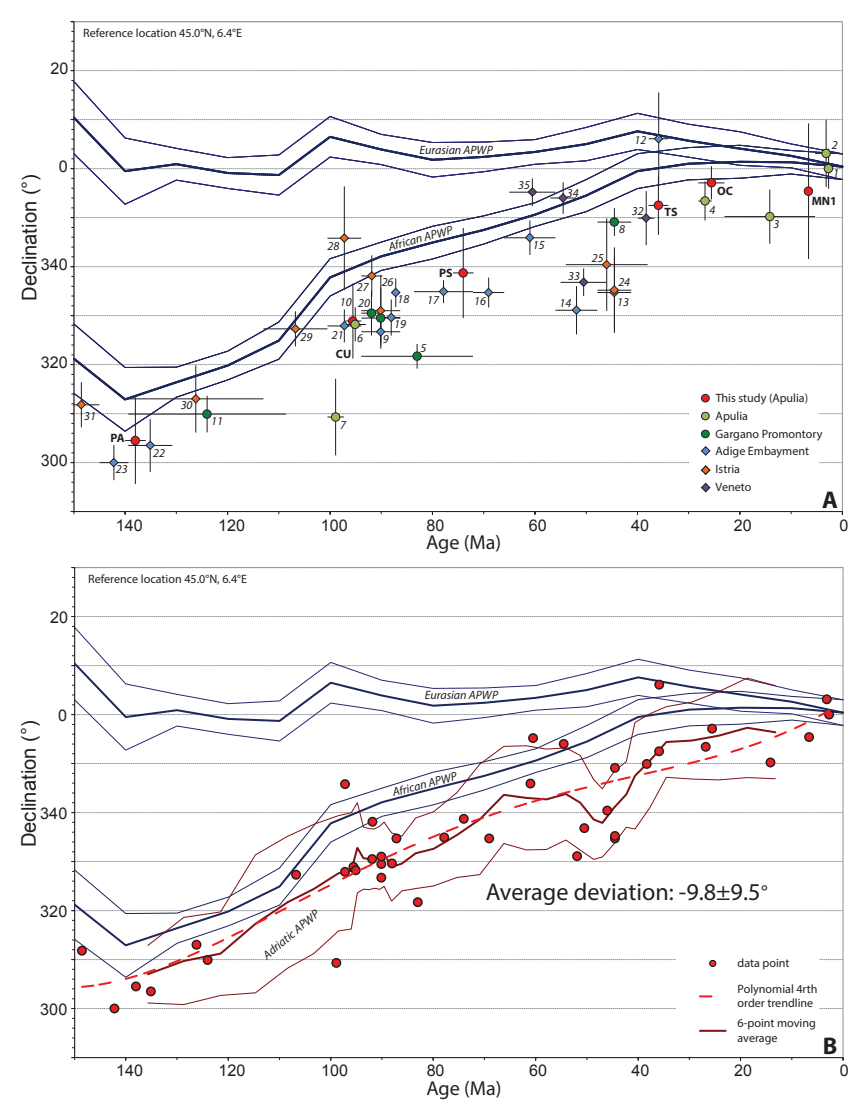

Figure 7. (A) Age (Ma, following the timescale of Gradstein et al., 2012) vs. declination plot for our new as well as published data from Adria. The error envelopes for the African and Eurasian APWPs are from Torsvik et al. (2012). Vertical error bars correspond to the $\Delta D$ calculated at each site (Table 1); horizontal error bars correspond to age uncertainty. All data are recalculated to a reference location $\left(45.0^{\circ} \mathrm{N}, 6.4^{\circ} \mathrm{E}\right)$ corresponding to the Neogene Apulia-Africa Euler pole proposed by Ustaszewski et al. (2008). Numbers and site abbreviations correspond to data entries in Table 1. (B) Same data, with a polynomial fourth-order trend line (purple dashed line) and the declination component of a full-vector six-point moving average with error bars $(\Delta D)$ (red line).

Figure 7a shows all declinations vs. age, from all four sectors of Adria. Approximately $40 \%$ of the poles are not statistically different from the expected African declinations. The remaining poles, representing the majority of the data set, consistently show small counterclockwise deviations from the African APWP. The data provide no support for significant rotations between the northern and southern sectors of Adria.

To calculate the magnitude of rotation of Adria with respect to Africa, we combine the data sets from the different regions. We used two approaches. One approach is to calculate a full-vector (six-point sliding window) moving average at every data point, from which we determined the $D$ values and a $\Delta D$ error envelope. The other approach is to calculate a (fourth-order) polynomial best fit based on declination val- ues only (Fig. 7b). Both approaches show a remarkably coincident pattern that display a systematic cew deviation of the mean declination of Adria relative to Africa from the entire Early Cretaceous to Late Cenozoic time interval. We interpolated the declination curve of the APWP of Africa (Torsvik et al., 2012) to obtain the declination at the ages corresponding to our moving average, and determined the difference at each data point. This yields an average deviation of all data of $9.8 \pm 9.5^{\circ} \mathrm{ccw}$.

This obtained magnitude is accidentally comparable to the total rotation of Adria calculated from the Upper Cretaceous of the Adige embayment and Istria by Márton et al. (2010). These authors, however, interpreted their total rotation as the result of two distinct phases of $\mathrm{cw}$ and $\mathrm{ccw}$ rotation. In particular, an average of Eocene rocks was interpreted by Márton et al. (2010) to show $30^{\circ} \mathrm{ccw}$ rotation of Adria versus Africa. They suggested a $\sim 20^{\circ} \mathrm{cw}$ rotation of Adria between the Cretaceous and Eocene, followed by a post-Eocene $\sim 30^{\circ}$ ccw rotation. These Eocene poles are included in our analysis, but taking all available data into account, we see no solid ground for interpreting significant rotation phases between the Early Cretaceous and the Late Cenozoic.

In summary, paleomagnetic data allow for a counterclockwise rotation of Adria relative to Africa anywhere between negligible $\left(1^{\circ}\right)$ and quite significant $\left(18^{\circ}\right)$ values, but with a very consistent average of $9.5^{\circ}$. The timing of this rotation is ill constrained, but can be estimated from the average declination shown in the graph of Fig. 7 to have occurred sometime in the second half of the Cenozoic, roughly $20 \pm 10 \mathrm{Ma}$.

\subsection{Regional kinematic implications}

The rotation pattern of Adria as emerging from this study can now be interpreted in the wider context of the central Mediterranean region. Our compilation of new and published paleomagnetic data do not lend support to models that infer either large Cretaceous vertical axis rotations (Dercourt et al., 1986; Márton et al., 2010) or a small cw rotation (Wortmann et al., 2001). We observe that two major types of scenarios can be accommodated within the range of rotation documented in this study (i.e., $1-18^{\circ} \mathrm{ccw}$ ). One type of scenario is put forward from an Alpine point of view (post-20 Ma, $\sim 20^{\circ} \mathrm{ccw}$ rotation of Adria relative to Europe around an Euler pole in the western Alps, corresponding to a $\sim 17^{\circ} \mathrm{ccw}$ rotation of Adria relative to Africa). The other type derives from an Ionian Basin point of view (assuming near-rigidity between Africa and Adria and hence no differential rotation, according to Rosenbaum et al., 2004). The paleomagnetically permissible rotation range derived here can therefore not discriminate the two end-member kinematic scenarios for Adria. Accordingly, we will show the kinematic consequences of the permitted minimum and maximum rotation of Adria as a function of the location of its Euler pole.

An Euler pole for the relative motion between Adria and Eurasia located at $45.0^{\circ} \mathrm{N}, 6.4^{\circ} \mathrm{E}$, near the city of Turin was 
computed by Ustaszewski et al. (2008) based on westward decreasing Neogene shortening in the Alps, and northward underthrusting of Adria below the southern Alps. Their inferred $20^{\circ} \mathrm{ccw}$ rotation relative to Eurasia translates into a paleomagnetically permitted $\sim 17^{\circ} \mathrm{ccw}$ rotation of Adria relative to Africa. Assuming internal rigidity of Adria, a rotation around this pole by $17^{\circ}$ would require up to $420 \mathrm{~km}$ of ENEWSW extension in the Ionian Basin measured at the modern southeasternmost tip of stable Adria along the Kefalonia Fault (Fig. 8a). This scenario would require that the entire Ionian Basin is Miocene in age, inconsistent with any of the inferred ages that range from Permian to Cretaceous. Similarly, a $9.5^{\circ}$ rotation of Adria (average rotation constrained by our paleomagnetic analysis) would yield $\sim 230 \mathrm{~km}$ of ENE-WSW extension, still much higher than what is geologically documented (Fig. 8b).

Adria could rotate ccw without extension in the Ionian Basin if the Adria-Africa Euler pole is located in the far southeast of Adria (Fig. 8c). Assuming Adriatic rigidity, and applying the $17^{\circ} \mathrm{ccw}$ rotation derived from reconstructions of the Alps, this would, however, lead to a reconstructed overlap of Adria and the Dinarides and Hellenides (which would suggest major Neogene extension in this area), and predicts $>400 \mathrm{~km}$ of E-W convergence in the western Alps. In contrast to this scenario, geological data from the Dinarides and Hellenides show Neogene shortening, uplift and exhumation (Bertotti et al., 2001; van Hinsbergen et al., 2006; Stojadinović et al., 2013), and the amount of Neogene shortening in the western Alps is much smaller than required by this scenario (e.g., Handy et al., 2010) (Fig. 8c).

Alternatively, we may explore the maximum amount of rotation around the Euler pole constrained by Ustaszewski et al. (2008) using constraints from the Ionian Sea and the Aegean region. The $\sim 40 \%$ crustal attenuation in the $140 \mathrm{~km}$ wide Sicily Channel (Civile et al., 2008) would suggest a (maximum) amount of NE-SW latest Miocene to PlioQuaternary extension between Adria and Africa of $\sim 40 \mathrm{~km}$. A similar amount of Adria-Africa relative motion since the Early Pliocene was inferred from a kinematic reconstruction of the Aegean region by van Hinsbergen and Schmid (2012) to avoid overlaps between Adria and the west Aegean foldthrust belt. This corresponds to a $1.7^{\circ} \mathrm{ccw}$ rotation of Adria. This reconstruction is consistent with the geological record of the circum-Ionian Basin, but it would require $\sim 150 \mathrm{~km}$ NW-SE-directed convergence between Adria and Europe since $20 \mathrm{Ma}$, to be accommodated in the western Alps, in contrast with widely accepted lower values of no more than some tens of kilometers (Ustaszewski et al., 2008; Handy et al., 2010) (Fig. 8d).

Our discussion above identifies an inconsistency between the kinematic interpretations from the geological record of the Alps and the Ionian Basin. Paleomagnetic data permit the scenarios that fulfill the constraints from both regions, but these scenarios cannot be reconciled with each other. More- over, the average rotation suggested by the paleomagnetic data violates both end-member scenarios.

Since a key assumption in the above analysis is the rigidity of Adria, we explore a final scenario whereby we decouple northern and southern Adria, e.g., along the Mid-Adriatic Ridge or along the Tremiti fault (Fig. 2), applying the reconstruction of Ustaszewski et al. (2008) for northern Adria (17 ccw rotation), and the reconstruction of van Hinsbergen and Schmid (2012) for southern Adria (1.7 $7^{\circ} \mathrm{ccw}$ rotation). This would require as much as $160 \mathrm{~km}$ of left-lateral strike-slip between northern and southern Adria, and none of the identified structures appear likely candidates to accommodate such major displacements (Fig. 8e).

The discussion above indicates that, although scenarios based on kinematic interpretations from both the Alps and the Ionian Basin infer Neogene Adria-Africa relative rotations that are within the range documented in this study, these scenarios are mutually exclusive. Paleomagnetic data alone cannot solve this "Adriatic enigma", but call for a reassessment of the kinematic evolution of three key areas, centered around the following questions: (i) since shortening reconstructions may underestimate the true amount of convergence - is the amount of Neogene shortening in the western Alps significantly underestimated? (ii) Is it possible to quantify the timing and amount of displacement along strike-slip zones that may separate a northern and southern Adria block? (iii) Is it possible that there is a large amount of Neogene extension along the Apulian escarpment, perhaps hidden below the advancing Calabrian prism and the Mediterranean ridge?

\section{Conclusions}

We provide six new paleomagnetic poles from the Lower Cretaceous to Upper Miocene of the Murge and Salento areas of the Apulian Platform, southern Italy. These new data, combined with recalculated published poles from the Gargano promontory, the Istrian peninsula of Croatia, and the Adige embayment of the southern Alps, constrain a counterclockwise rotation of Adria relative to Africa at $9.8 \pm 9.5^{\circ}$, occurring sometime after $20 \pm 10 \mathrm{Ma}$. Our revised paleomagnetic database for Adria discards significant rotations of Adria versus Africa between the Early Cretaceous and the Eocene, as invoked by several studies. The permissible rotation magnitude $\left(1-18^{\circ}\right.$ counterclockwise) is consistent with two end-member models for the central Mediterranean region requiring (i) a Neogene $\sim 18^{\circ}$ counterclockwise rotation of Adria relative to Africa (based on kinematic reconstruction of the Alps) or (ii) negligible rotation of Adria based on kinematic reconstruction of the Ionian Basin. Although paleomagnetic data from Adria are not in disagreement with both models, we establish that these scenarios are mutually exclusive. We cannot solve this enigma, but call for kinematic studies that will address the following three key questions: (i) was Neogene shortening in the western Alps 

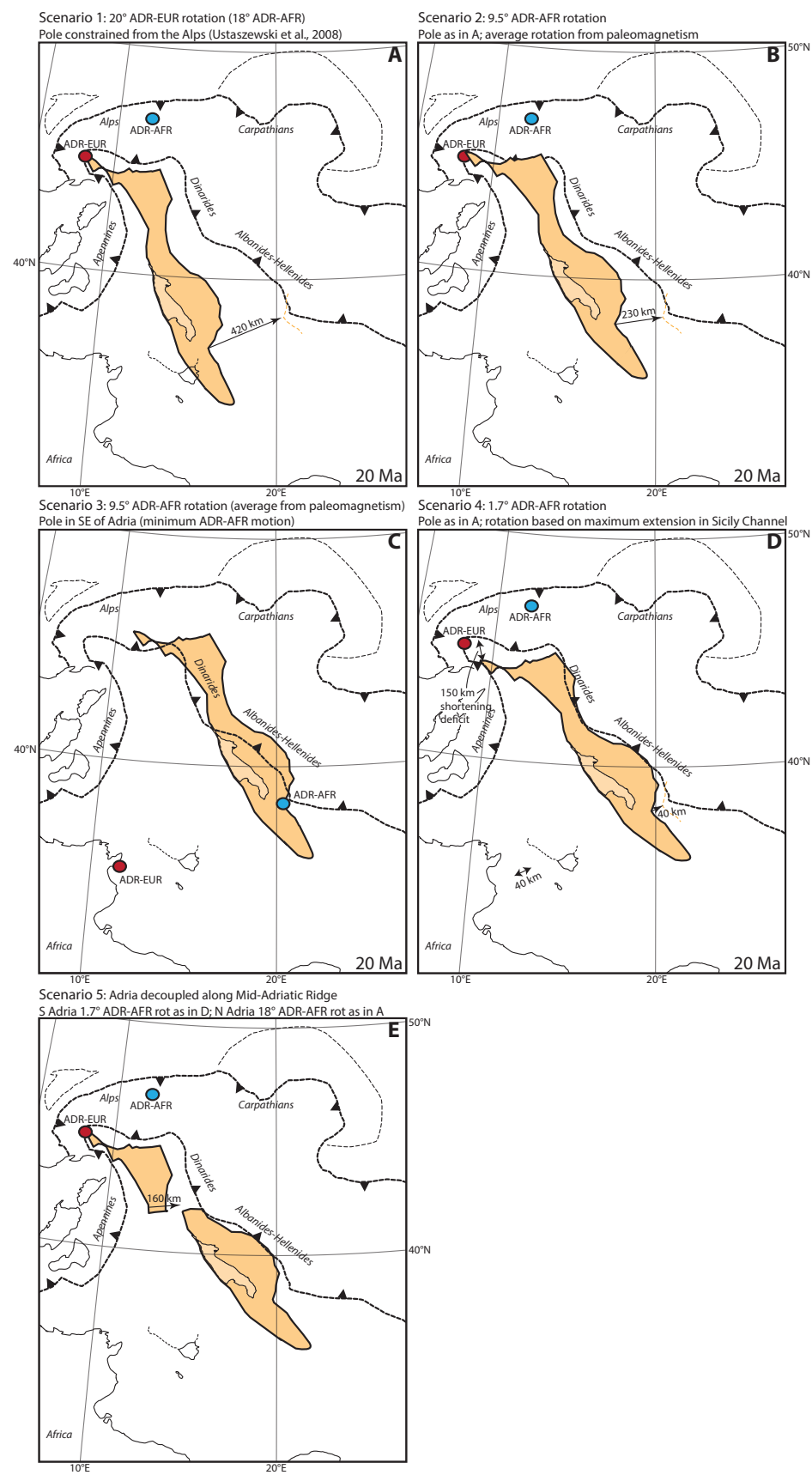

Figure 8. Reconstructions at $20 \mathrm{Ma}$ for rotation scenarios of Adria versus Africa that are permitted by paleomagnetic data, using (A) the rotation pole of Adria versus Eurasia of Ustaszewski et al. (2008), and a $20^{\circ} \mathrm{ccw}$ rotation of Adria versus Europe, corresponding to $18^{\circ} \mathrm{ccw}$ rotation of Adria versus Africa, constrained from shortening reconstructions in the Alps by the same authors; (B) a 9.5 ccw rotation of Adria versus Africa around the same pole corresponding to the paleomagnetically constrained mean rotation in this paper; $(\mathbf{C})$ a $9.5^{\circ} \mathrm{ccw}$ rotation of Adria versus Africa corresponding to the paleomagnetically constrained mean rotation in this paper, around a pole located in the SE of Adria and allowing minimum relative latitudinal motion between Africa and Adria; (D) a $1.7^{\circ}$ ccw rotation of Adria versus Africa around the pole of Ustaszewski et al. (2008), corresponding to the maximum amount of Neogene extension documented in the Sicily Channel; (E) decoupling northern and southern Adria along the Mid-Adriatic Ridge of Scisciani and Calamita (2009), with northern Adria following a scenario as in (A), and southern Adria following a scenario as in (D). Reconstructions of (i) the Adriatic front of the Alps, Carpathians and Dinarides follow Ustaszewski et al. (2008), (ii) the western Mediterranean region follow Faccenna et al. (2004) and van Hinsbergen et al. (2014), and (iii) the Aegean-Albanian region follow van Hinsbergen and Schmid (2012). Reconstruction is given in a Europe-fixed frame, with the position of Africa determined using rotation poles of Gaina et al. (2002) and Müller et al. (1999) for the North Atlantic and central Atlantic Ocean, respectively. 
significantly underestimated? (ii) Was Neogene extension in the Ionian Basin significantly underestimated? (iii) Was a northern Adria block decoupled from a southern Adria block along a large-offset sinistral strike-slip fault? Resolving these questions may lead to a solution of the conundrum associated with the kinematics of Adria.

Acknowledgements. Fieldwork was funded through the Netherlands research school of Integrated Solid Earth Sciences (ISES). D. J. J. van Hinsbergen and M. Maffione were supported by ERC Starting Grant 306810 (SINK) and an NWO VIDI grant to D. J. J. van Hinsbergen. L. Sabato, L. Spalluto and M. Tropeano were supported by Bari University funds (PRIN/COFIN 2009) grant to $\mathrm{M}$. Tropeano. We appreciated reviews of Gideon Rosenbaum and an anonymous reviewer.

Edited by: J. van Hunen

\section{References}

Agnini, C., Muttoni, G., Kent, D. V., and Rio, D.: Eocene biostratigraphy and magnetic stratigraphy from Possagno, Italy: The calcareous nannofossil response to climate variability, Earth Planet. Sci. Lett., 241, 815-830, 2006.

Agnini, C., Fornaciari, E., Giusberti, L., Grandesso, P., Lanci, L., Luciani, V., Muttoni, G., Pälike, H., Rio., D., Spofforth, D. J. A., and Stefani, C.: Integrated biomagnetostratigraphy of the Alano section (NE Italy): A proposal for defining the middle-late Eocene boundary, Geol. Soc. Am. Bull., 123, 841-872, 2011.

André, P. and Doulcet, A.: Rospo mare field - Italy, Apulian Platform, Adriatic Sea, in: "Treatise of Petroleum Geology, Atlas of Oil and Gas Fields, Stratigraphic Traps II", edited by: Foster, N. H. and Beaumont, E. A., AAPG, Tulsa, 29-54, 1991.

Argnani, A.: The strait of sicily rift zone: Foreland deformation related to the evolution of a back-arc basin, J. Geodynam., 12, 311331, 1990.

Argnani, A.: Evolution of the southern Tyrrhenian slab tear and active tectonics along the western edge of the Tyrrhenian subducted slab, Geological Society, London, Special Publications, 311, 193-212, 2009.

Argnani, A.: The influence of Mesozoic Palaeogeography on the variations in structural style along the front of the Albanide thrust-and-fold belt, IJG, 132, 175-185, 2013.

Argnani, A. and Bonazzi, C.: Malta Escarpment fault zone offshore eastern Sicily: Pliocene-Quaternary tectonic evolution based on new multichannel seismic data, Tectonics, 24, TC4009, doi:10.1029/2004TC001656, 2005.

Argnani, A., Marina, I. G., CNR, B., Favali, P., Frugoni, F., Gasperini, M., Ligi, M., Marani, M., and Mele, G.: Tettonica dell'Adriatico meridionale, Mem. Soc. Geol. It., 51, 227-237, 1996.

Argnani, A., Frugoni, F., Cosi, R., Ligi, M., and Favali, P.: Tectonics and seismicity of the Apulian Ridge south of Salento peninsula (Southern Italy), Ann. Geophys., 44, 527-540, 2001, http://www.ann-geophys.net/44/527/2001/.

Belguith, Y., Geoffroy, L., Mourgues, R., and Rigane, A.: Analogue modelling of Late Miocene-Early Quaternary continental crustal extension in the Tunisia-Sicily Channel area, Tectonophysics, 608, 576-585, 2013.

Bernoulli, D. and Jenkyns, H. C.: Ancient oceans and continental margins of the Alpine- Mediterranean Tethys: deciphering clues from Mesozoic pelagic sediments and ophiolites, Sedimentology, 56, 149-190, 2009.

Bertotti, G., Picotti, V., Chilovi, C., Fantoni, R., Merlini, S., and Mosconi, A.: Neogene to Quaternary sedimentary basins in the south Adriatic (Central Mediterranean): foredeeps and lithospheric buckling, Tectonics, 20, 771-787, 2001.

Bonardi, G., Amore, F. O., Ciampo, G., and de Capoa, P.: Complesso Liguride Auct.: stato delle conoscenze e problemi aperti sulla sua evoluzione pre-appenninica ed i suoi rapporti con 1'Arco Calabro, Memorie della Societa Geologica Italiana, 41, 17-35, 1988.

Bosellini, A.: Dinosaurs "re-write" the geodynamics of the eastern Mediterranean and the paleogeography of the Apulia Platform, Earth Sci. Rev., 59, 211-234, 2002.

Bosellini, A., Bosellini, F. R., Colalongo, M. L., Parente, M., Russo, A., and Vescogni, A.: Statigraphic architecture of the Salento coast from Capo d'Otranto to S. Maria di Leuca (Apulia, southern Italy), Rivista Italiana di Paleontologia e Stratigrafia, 105, 397-416, 1999a.

Bosellini, A., Morsilli, M., and Neri, C.: Long-term event stratigraphy of the Apulia Platform margin (Upper Jurassic to Eocene, Gargano, southern Italy), J. Sed. Res., 69, 1241-1252, 1999b.

Bosellini, F. R.: Biotic changes and their control on OligoceneMiocene reefs: A case study from the Apulia Platform margin (southern Italy), Palaeogeogr. Palaeocl., 241, 393-409, 2006.

Bosellini, F. R. and Russo, A.: Stratigraphy and facies of an Oligocene fringing reef (Castro Limestone, Salento Peninsula, southern Italy), Facies, 26, 145-165, 1992.

Bosellini, F. R., Russo, A., and Vescogni, A.: Messinian reefbuilding assemblages of the Salento Peninsula (southern Italy): palaeobathymetric and palaeoclimatic significance, Palaeogeogr. Palaeocl., 175, 7-26, 2001.

Butler, R. F.: Paleomagnetism: Magnetic Domains to Geologic Terranes, Blackwell Scientific Publications, Boston. 1992.

Capitanio, F. A. and Goes, S.: Mesozoic spreading kinematics: consequences for Cenozoic Central and Western Mediterranean subduction, Geophys. J. Internat., 165, 804-816, 2006.

Capitanio, F. A., Faccenna, C., Funiciello, R., and Salvini, F.: Recent tectonics of Tripolitania, Libya: an intraplate record of Mediterranean subduction, Geological Society, London, Special Publications, 357, 319-328, 2011.

Carminati, E., Lustrino, M., and Doglioni, C.: Geodynamic evolution of the central and western Mediterranean: Tectonics vs. igneous petrology constraints, Tectonophysics, 579, 173-192, 2012.

Catalano, R., Doglioni, C., and Merlini, S.: On the mesozoic Ionian basin, Geophys. J. Internat., 144, 49-64, 2001.

Cavazza, W., Ziegler, P. A., Spakman, W., and Stampfi, G.: The TRANSMED Atlas, Heidelberg, 1-127, 2004.

Chamot-Rooke, N. and Rangin, C.: DOTMED-Deep Offshore Tectonics of the Mediterranean: A synthesis of deep marine data in eastern Mediterranean, Mem. Soc. Geol. Fr, 177, 1-64, 2005.

Channell, J.: Palaeomagnetism of limestones from the Gargano Peninsula (Italy), and the implication of these data, Geophys. J. Roy. Astronom. Soc., 51, 605-616, 1977. 
Channell, J. and Tarling, D. H.: Palaeomagnetism and the rotation of Italy, Earth Planet. Sci. Lett., 25, 177-188, 1975.

Channell, J., D'Argenio, B., and Horvath, F.: Adria, the African promontory, in Mesozoic Mediterranean palaeogeography, Earth Sci. Rev., 15, 213-292, 1979.

Channell, J. E. T.: Palaeomagnetism and palaeogeography of Adria, Geological Society, London, Special Publications, 105, 119-132, 1996.

Channell, J. E. T., Casellato, C. E., Muttoni, G., and Erba, E.: Magnetostratigraphy, nannofossil stratigraphy and apparent polar wander for Adria-Africa in the Jurassic - Cretaceous boundary interval, Palaeogeogr. Palaeocl., 293, 51-75, 2010.

Ciaranfi, N., Pieri, P., and Ricchetti, G.: Note alla carta geologica delle Murge, Mem. Soc. Geol. It., 41, 449-460, 1988.

Cifelli, F., Mattei, M., and Rossetti, F.: Tectonic evolution of arcuate mountain belts on top of a retreating subduction slab: The example of the Calabrian Arc, J. Geophys. Res., 112, B09101, doi:10.1029/2006JB004848, 2007.

Civile, D., Lodolo, E., Tortorici, L., Lanzafame, G., and Brancolini, G.: Relationships between magmatism and tectonics in a continental rift: The Pantelleria Island region (Sicily Channel, Italy), Mar. Geol., 251, 32-46, 2008.

Civile, D., Lodolo, E., Accettella, D., and Geletti, R.: The Pantelleria graben (Sicily Channel, central Mediterranean): an example of intraplate "passive"rift, Tectonophysics, 490, 174-183, 2010.

Creer, K. M., Irving, A. J., and Nairn, A. E. M.: Paleomagnetism of the Great Whin Sill, Geophys. J. Roy. Astronom. Soc., 2, 306323, 1959.

D’Agostino, N., Avallone, A., Cheloni, D., D’Anastasio, E., Mantenuto, S., and Selvaggi, G.: Active tectonics of the Adriatic region from GPS and earthquake slip vectors, J. Geophys. Res., 113, B12413, doi:10.1029/2008JB005860, 2008.

Dallanave, E., Agnini, C., Muttoni, G.. and Rio, D.: Magnetobiostratigraphy of the Cicogna section (Italy): Implications for the late Paleocene-early Eocene time scale, Earth Planet. Sci. Lett., 285, 39-51, 2009.

Dallanave, E., Agnini, C., Muttoni, G., and Rio, D.: Paleocene magneto- biostratigraphy and climate-controlled rock magnetism from the Belluno Basin, Tethys Ocean, Italy, Palaeogeogr. Palaeocl., 337/338, 130-142, 2012.

D’Argenio, B., Pescatore, T.. and Scandone, P.: Schema geologico dell'Appennino meridionale (Campania e Lucania), Accademia Nazionale dei Lincei, 183, 49-72, 1973.

de Alteriis, G.: Different foreland basins in Italy: examples from the central and southern Adriatic Sea, Tectonophysics, 252, 349373, 1995.

Deenen, M. H. L., Langereis, C. G., van Hinsbergen, D. J. J., and Biggin, A. J.: Geomagnetic secular variation and the statistics of palaeomagnetic directions, Geophys. J. Internat., 186, 509-520, 2011.

Del Ben, A., Geletti, R., and Mocnik, A.: Relation between recent tectonics and inherited Mesozoic structures of the centralsouthern Adria plate, Bollettino di Geofisica Teoretica ed Applicata, 51, 99-115, 2010.

Dercourt, J., Zonenshain, L.P., Ricou, L. E., and Kazmin, V. G.: Geological evolution of the Tethys belt from the Atlantic to the Pamirs since the Lias, Tectonophysics, 123, 241-315, 1986.
Dewey, J. F., Helman, M. L., Knott, S. D., Turco, E., and Hutton, D. H. W.: Kinematics of the western Mediterranean, Geological Society, London, Special Publications, 45, 265-283, 1989.

Doglioni, C.: A proposal for the kinematic modelling of W-dipping subductions - possible applications to the Tyrrhenian-Apennines system, Terra Nova, 3, 423-434, 1991.

Doglioni, C., Mongelli, F., and Pieri, P.: The Puglia uplift (SE Italy): An anomaly in the foreland of the Apenninic subduction due to buckling of a thick continental lithosphere, Tectonics, 13, 13091321, 1994.

Doglioni, C., Gueguen, E., Sabàt, F., and Fernandez, M.: The Western Mediterranean extensional basins and the Alpine orogen, Terra Nova 9, 109-112, 1997.

Faccenna, C. and Becker, T. W.: Shaping mobile belts by smallscale convection, Nature, 465, 602-605, 2010.

Faccenna, C., Funiciello, F., Giardini, D., and Lucente, P.: Episodic back-arc extension during restricted mantle convection in the Central Mediterranean, Earth Planet. Sc. Lett., 187, 105-116, 2001.

Faccenna, C., Piromallo, C., Crespo-Blanc, A., Jolivet, L., and Rossetti, F.: Lateral slab deformation and the origin of the western Mediterranean arcs, Tectonics, 23, TC1012 doi:10.1029.2002TC001488, 2004.

Fantoni, R. and Franciosi, R.: Tectono-sedimentary setting of the Po Plain and Adriatic foreland, Rend. Fis. Acc. Lincei, 21, 197-209, 2010.

Favali, P., Mele, G., and Mattietti, G.: Contribution to the study of the Apulian microplate geodynamics, Mem. Soc. Geol. It., 44, 71-80, 1990.

Favali, P., Funiciello, R., Mattietti, G., Mele, G., and Salvini, F.: An active margin across the Adriatic Sea (central Mediterranean Sea), Tectonophysics, 219, 109-117, 1993.

Favre, P. and Stampfli, G. M.: From rifting to passive margin: the examples of the Red Sea, Central Atlantic and Alpine Tethys, Tectonophysics, 215, 69-97, 1992.

Festa, V.: Cretaceous structural features of the Murge area (Apulian Foreland, Southern Italy), Eclogae Geol. Helv., 96, 11-22, 2003.

Festa, V., Tropeano, M., and Sabato, L.: New insights on diapirism in the Adriatic Sea: the Tremiti salt structure (Apulia offshore, southeastern Italy), Terra Nova, 26, 169-178, 2014.

Finetti, I.: Structure, stratigraphy and evolution of the central Mediterranean Sea, Bolletino di Geofisica Teoretica ed Applicata, 24, 247-312, 1982.

Finetti, I.: Structure and Evolution of the Central Mediterranean (Pelagian and Ionian Seas), Springer New York, New York, NY, 215-230, 1985.

Fisher, R. A.: Dispersion on a sphere, Proc. Roy. Soc. Lond., A217, 295-305, 1953.

Flores, G., Pieri, M., and Sestini, G.: Geodynamic history and petroleum habitats of the south-east Adriatic region, AAPG Special Publication, 1, 389-398, 1991.

Frisch, W.: Tectonic progradation and plate tectonic evolution of the Alps, Tectonophysics, 60, 121-139, 1979.

Frizon de Lamotte, D., Raulin, C., Mouchot, N., Wrobel-Daveau, J.C., Blanpied, C., and Ringenbach, J.-C.: The southernmost margin of the Tethys realm during the Mesozoic and Cenozoic: Initial geometry and timing of the inversion processes, Tectonics, 30, TC3002, doi:10.1029.2010TC002691, 2011. 
Gaina, C., Roest, W. R., and Müller, R. D.: Late CretaceousCenozoic deformation of northeast Asia, Earth Planet. Sci. Lett., 197, 273-286, 2002.

Gaina, C., Torsvik, T. H., van Hinsbergen, D. J. J., Medvedev, S., Werner, S. C., and Labails, C.: The African Plate: A history of oceanic crust accretion and subduction since the Jurassic, Tectonophysics, 604, 4-25, 2013.

Gallais, F., Gutscher, M.-A., Graindorge, D., Chamot-Rooke, N., and Klaeschen, D.: A Miocene tectonic inversion in the Ionian Sea (central Mediterranean): Evidence from multichannel seismic data, J. Geophys. Res., 116, B12108, doi:10.1029.2011JB008505, 2011.

Gambini, R. and Tozzi, M.: Tertiary geodynamic evolution of the Southern Adria microplate, Terra Nova, 8, 593-602, 1996.

Goes, S., Giardini, D., Jenny, S., Hollenstein, C., Kahle, H. G., and Geiger, A.: A recent tectonic reorganization in the south-central Mediterranean, Earth Planet. Sci. Lett., 226, 335-345, 2004.

Golonka, J.: Plate tectonic evolution of the southern margin of Eurasia in the Mesozoic and Cenozoic, Tectonophysics, 381, 235273, 2004

Govers, R. and Wortel, M. J. R.: Lithosphere tearing at STEP faults: Response to edges of subduction zones, Earth Planet. Sci. Lett., 236, 505-523, 2005.

Gradstein, F. M., Ogg, J. G., Schmitz, M., and Ogg, G.: The Geologic Time Scale 2012, Elsevier, Amsterdam, 2012.

Grandic, S., Biancone, M., and Samarzija, J.: Geophysical and stratigraphic evidence of the Triassic rift structuration in the Adriatic offshore area, Mem. Soc. Geol. It., 57, 315-325, 2002.

Gueguen, E., Doglioni, C., and Fernandez, M.: On the post-25 Ma geodynamic evolution of the western Mediterranean, Tectonophysics, 298, 259-269, 1998.

Handy, M. R., Schmid, S. M., Bousquet, R., Kissling, E., and Bernoulli, D.: Reconciling plate-tectonic reconstructions of Alpine Tethys with the geological-geophysical record of spreading and subduction in the Alps, Earth Sci. Rev., 102, 121-158, 2010.

Hieke, W., Cita, M. B., and Forcella, F.: Geology of the Victor Hensen Seahill (Ionian Sea, eastern Mediterranean); insights from the study of cored sediment sequences, Boll. Soc. Geol. Italiana, 125, 245-257, 2006.

Iannone, A. and Laviano, A.: Studio stratigrafico e paleoambientale di una successione cenomaniano-turoniana (Calcare di Bari) affiorante presso Ruvo di Puglia, Geologica Romana, 1980.

Johnson, C. L., Constable, C. G., Tauxe, L., Barendregt, R., Brown, L. L., Coe, R. S., Layer, P., Mejia, V., Opdyke, N. D., Singer, B. S., Staudigel, H., and Stone, D. B.: Recent investigations of the $0-5 \mathrm{Ma}$ geomagnetic field recorded by lava flows, Geochem. Geophys. Geosys., 9, Q04032, doi:10.1029.2007GC001696, 2008

Jolivet, L., Faccenna, C., and Piromallo, C.: From mantle to crust: Stretching the Mediterranean, Earth Planet. Sci. Lett., 285, 198209, 2009

Kastelic, V., Vannoli, P., Burrato, P., Fracassi, U., Tiberti, M. M., and Valensise, G.: Marine and Petroleum Geology, Mar. Petrol. Geol., 42, 191-213, 2013.

Kirschvink, J. L.: The least-squares line and plane and the analysis of palaeomagnetic data, Geophys. J. Roy. Astronom. Soc., 62, 699-718, 1980 .
Kokkalas, S., Kamberis, E., Xypolias, P., and Sotiropoulos, S.: Coexistence of thin-and thick-skinned tectonics in Zakynthos area (western Greece): Insights from seismic sections and regional seismicity, Tectonophysics, 597-598, 73-84, 2012.

Laviano, A., Maresca, M. G., and Tropeano, M.: Stratigraphic organization of rudist biogenic beds in the Upper Cenomanian successions of the Western Murge (Apulia, Southern Italy), Geobios, 31, 159-168, 1998.

Luperto-Sinni, E. and Masse, J.-P.: Données nouvelles sur la micropaléontologie et la stratigraphie de la partie basale du " "Calcare di Bari" (Crétacé inférieur) dans la région des Murges (Italie méridionale), Rivista Italiana di Paleontologia e Stratigrafia, 90, 331-374, 1984.

Malinverno, A. and Ryan, W. B. F.: Extension in the Tyrrhenian Sea and shortening in the Apennines as result of arc migration driven by sinking of the lithosphere, Tectonics, 5, 227-245, 1986.

Márton, E. and Nardi, G.: Cretaceous palaeomagnetic results from Murge (Apulia, southern Italy) : tectonic implications, Geophys. J. Internat., 119, 842-856, 1994.

Márton, E., Drobne, J., Ćosović, V., and Moro, A.: Palaeomagnetic evidence for Tertiary counterclockwise rotation of Adria, Tectonophysics, 377, 143-156, 2003.

Márton, E., Ćosović, V., Moro, A. and Zvocak, S.: The motion of Adria during the Late jurassic and Cretacous: New paleomagnetic results from stable Istria, Tectonophysics, 454, 44-53, 2008.

Márton, E., Zampieri, D., Grandesso, P., Ćosović, V., and Moro, A.: New Cretaceous paleomagnetic results from the foreland of the Southern Alps and the refined apparent polar wander path for stable Adria, Tectonophysics, 480, 57-72, 2010.

Márton, E., Zampieri, D., Kázmér, M., Dunkl, I., and Frisch, W.: New Paleocene-Eocene paleomagnetic results from the foreland of the Southern Alps confirm decoupling of stable Adria from the African plate, Tectonophysics, 504, 89-99, 2011.

Mastrogiacomo, G., Moretti, M., Owen, G., and Spalluto, L.: Tectonic triggering of slump sheets in the Upper Cretaceous carbonate succession of the Porto Selvaggio area (Salento peninsula, southern Italy): Synsedimentary tectonics in the Apulian Carbonate Platform, Sediment. Geol., 269, 15-27, 2012.

Mattavelli, L., Novelli, L., and Anelli, L.: Occurrence of hydrocarbons in the Adriatic basin, AAPG Special Publication, 1, 369380, 1991.

McFadden and McElhinny, M. W.: Classification of the reversal test in palaeomagnetism, Geophys. J. Internat., 103, 725-729, 1990.

Minelli, L. and Faccenna, C.: Evolution of the Calabrian accretionary wedge (central Mediterranean), Tectonics, 29, TC4004, doi:10.1029.2009TC002562, 2010.

Mullender, T. A. T., Van Velzen, A. J., and Dekkers, M. J.: Continuous drift correction and separate identification of ferrimagnetic and paramagnetic contribution in thermamagnetic runs, Geophys. J. Internat., 114, 663-672, 1993.

Müller, R. D., Royer, J.-Y., Cande, S. C., Roest, W. R., and Maschenkov, S.: New constraints on the Late Cretaceous/Tertiary plate tectonic evolution of the Caribbean, Sediment. Basins World, 4, 33-59, 1999.

Muttoni, G., Erba, E., Kent, D. V., and Bachtadse, V.: Mesozoic Alpine facies deposition as a result of past latitudinal plate motion, Nature, 434, 59-63, 2005. 
Muttoni, G., Dallanave, E., and Channell, J. E. T.: The drift history of Adria and Africa from $280 \mathrm{Ma}$ to Present, Jurassic true polar wander, and zonal climate control on Tethyan sedimentary facies, Palaeogeogr. Palaeocl., 386, 415-435, 2013.

Oldow, J. S., Ferranti, L., D’Argenio, B., Catalano, R., and Pappone, G.: Active fragmentation of Adria, the north African promontory, central Mediterranean orogen, Geology, 30, 779-774, 2002.

Parente, M.: A revised stratigraphy of the Upper Cretaceous to Oligocene units from southeastern Salento (Apulia, southern Italy), Boll. Soc. Paleont. Ital., 33, 155-170, 1994.

Pasquale, V., Verdoya, M., and Chiozzi, P.: Thermal Structure of the Ionian Slab, Pure Appl. Geophys., 162, 967-986, 2005.

Picha, F. J.: Late orogenic strike-slip faulting and escape tectonics in frontal Dinarides-Hellenides, Croatia, Yugoslavia, Albania, and Greece, AAPG Bulletin, 86, 1659-1671, 2002.

Pieri, P. and Laviano, A.: Tettonica e sedimentazione nei depositi senoniani delle Murge sud-orientali (Ostuni), Bollettino della Società Geologica Italiana, 108, 351-356, 1989.

Pieri, P., Festa, V., Moretti, M., and Tropeano, M.: Quaternary tectonic activity of the Murge area (Apulian foreland - Southern Italy), Ann. Geophys., 40, 1395-1404, 1997,

http://www.ann-geophys.net/40/1395/1997/.

Pomar, L., Mateu-Vicens, G., Morsilli, M., and Brandano, M. : Carbonate ramp evolution during the Late Oligocene (Chattian), Salento Peninsula, southern Italy, Palaeogeogr. Palaeocl., 404, 109-132, 2014.

Reina, A. and Luperto-Sinni, E.: Contributo alla conoscenza stratigrafica del Cretaceo superiore in facies di piattaforma carbonatica interna del Salento occidentale (Puglia, Italia meridionale), Boll. Soc. Geol. Italiana, 33, 145-153, 1994a.

Reina, A. and Luperto-Sinni, E.: Le Dolomie di Monte S. Elia: proposta per una nuova unità formazionale del Cretaceo delle Murge (Puglia, Italia meridionale), Paleopelagos, 4, 233-241, 1994b.

Reston, T. J., Huene, von, R., Dickmann, R., Klaeschen, D., and Kopp, H.: Frontal accretion along the western Mediterranean Ridge: the effect of Messinian evaporites on wedge mechanics and structural style, Mar. Geol., 186, 59-82, 2002.

Ricchetti, G.: Nuovi dati stratigrafici sul Cretaceo delle Murge emersi da indagini nel sottosuolo, Bolletino di Societa Geologica Italiana, 94, 1083-1108, 1975.

Ricchetti, G., Ciaranfi, N., Luperto-Sinni, E., Mongelli, F., and Pieri, P.: Geodinamica ed evoluzione sedimentaria e tettonica dell'avampaese apulo, Mem. Soc. Geol. It., 41, 57-82, 1998.

Robertson, A. H. F., Clift, P. D., Degnan, P. J., and Jones, G.: Palaeogeographic and palaeotectonic evolution of the Eastern Mediterranean Neotethys, Palaeogeogr. Palaeocl., 87, 289-343, 1991.

Rosenbaum, G. and Lister, G. S.: Formation of arcuate orogenic belts in the western Mediterranean region, Orogenic curvature: integrating paleomagnetic and structural analyses, 41-56, 2004.

Rosenbaum, G. and Lister, G. S.: The Western Alps from the Jurassic to Oligocene: spatio-temporal constraints and evolutionary reconstructions, Earth Sci. Rev., 69, 281-306, 2005.

Rosenbaum, G., Lister, G. S., and Duboz, C.: Relative motions of Africa, Iberia and Europe during Alpine orogeny, Tectonophysics, 359, 117-129, 2002.

Rosenbaum, G., Lister, G. S., and Duboz, C.: The Mesozoic and Cenozoic motion of Adria (central Mediterranean): a review of constraints and limitations, Geodinam. Acta, 17, 125-139, 2004.
Rosenbaum, G., Gasparon, M., Lucente, F. P., Peccerillo, A., and Miller, M. S.: Kinematics of slab tear faults during subduction segmentation and implications for Italian magmatism, Tectonics, 27, TC2008, doi:10.1029.2007TC002143, 2008.

Royden, L. H. and Papanikolaou, D. J.: Slab segmentation and late Cenozoic disruption of the Hellenic arc, Geochem. Geophys. Geosyst., 12, Q03010, doi:10.1029.2010GC003280, 2011.

Savostin, L. A., Sibuet, J. C., Zonenshain, L.P., Le Pichon, X., and Roulet, M.-J.: Kinematic evolution of the Tethys belt from the Atlantic Ocean to the Pamirs since the Triassic, Tectonophysics, 123, 1-35, 1986.

Scheepers, P.: No tectonic rotation for the Apulia-Gargano foreland in the Pleistocene, Geophys. Res. Lett., 19, 2275-2278, 1992.

Schettino, A. and Turco, E.: Tectonic history of the western Tethys since the Late Triassic, Geol. Soc. Am. Bull., 123, 89-105, 2011.

Schmid, S. M., Bernoulli, D., Fügenschuh, B., Maţenco, L., Schefer, S., Schuster, R., Tischler, M., and Ustaszewski, K.: The AlpineCarpathian-Dinaridic orogenic system: correlation and evolution of tectonic units, Swiss J Geosci, 101, 139-183, 2008.

Schmid, S. M., Scharf, A., Handy, M. R., and Rosenberg, C. L.: The Tauern Window (Eastern Alps, Austria): a new tectonic map, with cross-sections and a tectonometamorphic synthesis, Swiss J. Geosci., 106, 1-32, 2013.

Schönborn, G.: Balancing cross sections with kinematic constraints: The Dolomites (northern Italy), Tectonics, 18, 527-545, 1999.

Scisciani, V. and Calamita, F.: Active intraplate deformation within Adria: Examples from the Adriatic region, Tectonophysics, 476, 57-72, 2009.

Scrocca, D.: Thrust front segmentation induced by differential slab retreat in the Apennines (Italy), 18, 154-161, 2006.

Sengör, A. M. C., Yilmaz, Y., and Sungurlu, O.: Tectonics of the Mediterranean Cimmerides: nature and evolution of the western termination of Palaeo-Tethys, Geological Society, London, Special Publications, 17, 77-112, 1984.

Seton, M., Müller, R. D., Zahirovic, S., Gaina, C., Torsvik, T. H., Shephard, G., Talsma, A., Gurnis, M., Turner, M., Maus, S., and Chandler, M.: Global continental and ocean basin reconstructions since 200 Ma, Earth Sci. Rev., 113, 212-270, 2012.

Sinni, E. L. and Borgomano, J.: Le Crétacé supérieur des Murges sud-orientales (Italie méridionale): stratigraphie et évolution des paléoenvironnements, Rivista Italiana di Paleontologia e Stratigrafia, 95, 95-136, 1989.

Spalluto, L.: Facies evolution and sequence chronostratigraphy of a "mid-"Cretaceous shallow-water carbonate succession of the Apulia Carbonate Platform from the northern Murge area (Apulia, southern Italy), Facies, 58, 17-36, 2011.

Spalluto, L. and Caffau, M.: Stratigraphy of the mid-Cretaceous shallow-water limestones of the Apulia Carbonate Platform (Murge, Apulia, southern Italy), IJG, 129, 335-352, 2010.

Spalluto, L., Pieri, P., and Ricchetti, G.: Le facies carbonatiche di piattaforma interna del Promontorio del Gargano; implicazioni paleoambientali e correlazioni con la coeva successione delle Murge (Italia meridionale, Puglia), IJG, 124, 675-690, 2005.

Speranza, F. and Kissel, C.: First paleomagnetism of eocene rocks from Gargano: Widespread overprint or non rotation? Geophys. Res. Lett., 20, 2627-2630, 1993.

Speranza, F., Minelli, L., Pignatelli, A., and Chiappini, M.: The Ionian Sea: The oldest in situ ocean fragment of the world?, J. Geophys. Res., 117, B12101, doi:10.1029.2012JB009475, 2012. 
Stampfli, G. M. and Borel, G. D.: A plate tectonic model for the Paleozoic and Mesozoic constrained by dynamic plate boundaries and restored synthetic oceanic isochrons, Earth Planet. Sci. Lett., 196, 17-33, 2002.

Stampfli, G. M. and Hochard, C., Eds.: Plate tectonics of the Alpine realm, Geological Society, London, Special Publications, 327, 89-111, 2009.

Stampfli, G. M. and Mosar, J.: The making and becoming of Apulia, Mem. Sci. Geol., 51, 141-154, 1999.

Stojadinović, U., Matenco, L., and Andriessen, P.: The balance between orogenic building and subsequent extension during the Tertiary evolution of the NE Dinarides: Constraints from lowtemperature thermochronology, Glob. Planet. Change, 103, 1938, 2013.

Tauxe, L. and Kent, D. V.: A simplified statistical model for the geomagnetic field and the detection of shallow bias in paleomagnetic inclinations: Was the ancient magnetic field dipolar? Timescales of the Paleomagnetic field, Geophys. Monogr. Ser., 145, 101$115,2004$.

Torsvik, T. H., Van der Voo, R., Preeden, U., Mac Niocaill, C., Steinberger, B., Doubrovine, P. V., van Hinsbergen, D. J. J., Domeier, M., Gaina, C., Tohver, E., Meert, J. G., McCausland, P. J. A., and Cocks, L. R. M.: Phanerozoic polar wander, paleogeography and dynamics, Earth Sci. Rev., 114, 325-368, 2012.

Tozzi, M., Kissel, C., Funiciello, R., Laj, C., and Parotto, M.: A clockwise rotation of southern Apulia?, Geophys. Res. Lett., 15, 681-684, 1988.

Tropeano, M., Spalluto, L., Moretti, M., Pieri, P., and Sabato, L.: Depositi carbonatici infrapleistocenici di tipo Foramol in sestemi di scarpata (Salento-Italia Meridionale), Il Quaternario, 17, 537546, 2004.

Underhill, J. R.: Late Cenozoic deformation of the Hellenide foreland, western Greece, Geol. Soc. Am. Bull., 101, 613-634, 1989.

Ustaszewski, K., Schmid, S. M., Fügenschuh, B., Tischler, M., Kissling, E. and Spakman, W.: A map-view restoration of the Alpine-Carpathian-Dinaridic system for the Early Miocene, Swiss J. Geosci., 101, 273-294, 2008.

Vai, G. B. and Martini, I. P.: Anatomy of an orogen: the Apennines and adjacent Mediterranean basins, Springer-science+business Media B.V., Dordrecht, 2001.
Vandenberg, J.: Reappraisal of paleomagnetic data from Gargano (South Italy), Tectonophysics, 98, 29-41, 1983.

van Hinsbergen, D. J. J. and Schmid, S. M.: Map view restoration of Aegean-West Anatolian accretion and extension since the Eocene, Tectonics, 31, TC5005, doi:10.1029/2012TC003132, 2012.

van Hinsbergen, D. J. J., van der Meer, D. G., Zachariasse, W. J., and Meulenkamp, J. E.: Deformation of western Greece during Neogene clockwise rotation and collision with Apulia, Internat. J. Earth Sci., 95, 463-490, 2006.

van Hinsbergen, D., Vissers, R., and Spakman, W.: Origin and consequences of western Mediterranean subduction, rollback, and slab segmentation, Tectonics, 33, 393-419, doi:10.1002/2013TC003349, 2014.

Vescogni, A.: Evoluzione delle biocostruzioni a vermetidi e loro utilizzo come "markers" paleobatimetrici e paleoclimatici, Giornale di Geologia, 62, 55-61, 2000.

Vissers, R., van Hinsbergen, D., and Meijer, P. T.: Kinematics of Jurassic ultra-slow spreading in the Piemonte Ligurian ocean, Earth Planet. Sci. Lett., 380, 138-150, 2013.

Vlahović, I., Tišljar, J., Velić, I., and Matičec, D.: Evolution of the Adriatic Carbonate Platform: Palaeogeography, main events and depositional dynamics, Palaeogeography, 220, 333-360, 2005.

Wortel, M. J. R. and Spakman, W.: Subduction and slab detachment in the Mediterranean-Carpathian region, Science, 290, 1910 1917, 2000.

Wortmann, U. G., Weissert, H., Funk, H., and Hauck, J.: Alpine plate kinematics revisited: The Adria Problem, Tectonics, 20, 134-147, 2001.

Zappaterra, E.: Carbonate paleogeographic sequences of the peradriatic region, Bolletino di Societa Geologica Italiana, 109, 520, 1990 .

Zappaterra, E.: Source-Rock Distribution Model of the Periadriatic Region, AAPG Bulletin, 78, 333-354, 1994.

Zijderveld, J. D. A.: A.C. demagnetization of rocks: analysis of results, in Methods in Palaeomagnetism, Elsevier, Amsterdam, New York, 254-286, 1967. 